\title{
BENCH-SCALE EVAPORATION OF A LARGE HANFORD ENVELOPE C
}

\section{SAMPLE (Tank 241-AN-102)}

May 2001

Mark L. Crowder, Charles L. Crawford, Hiroshi H. Saito, T. Bond Calloway, Jr., Luther V. Gibson, Jr. ${ }^{\dagger}$, Mark A. Burdette ${ }^{\dagger}$, Stephen L. Crump

${ }^{\dagger}$ BWXT Y-12, L.L.C., Y-12 National Security Complex, Oak Ridge, TN

UNCLASSIFIED

DOES NOT CONTAIN

UNCLASSIFIED CONTROLLED

NUCLEAR INFORMATION

ADC \&

Reviewing

Official:

H. F. Sturm Jr., SRTC Project Manager

Date:

\section{Disclaimer}

This report was prepared by Westinghouse Savannah River Company (WSRC) for the United States Department of Energy under Contract No. DE-AC09-96SR18500 and is an account of work performed under that contract. Neither the United States Department of Energy, nor WSRC, nor any of their employees makes any warranty, expressed or implied, or assumes any legal liability or responsibility for accuracy, completeness, or usefulness, of any information, apparatus, or product or process disclosed herein or represents that its use will not infringe privately owned rights. Reference herein to any specific commercial product, process, or service by trade name, trademark, name, manufacturer or otherwise does not necessarily constitute or imply endorsement, recommendation, or favoring of same by WSRC or by the United States Government or any agency thereof. The views and opinions of the authors expressed herein do not necessarily state or reflect those of the United States Government or any agency thereof.

Westinghouse Savannah River Company

Savannah River Site

Aiken, SC 29808

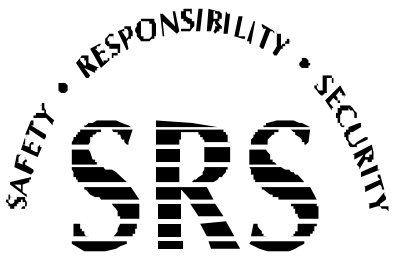


This document was prepared in conjunction with work accomplished under Contract No.

DE-AC09-96SR18500 with the U.S. Department of Energy.

\section{DISCLAIMER}

This report was prepared as an account of work sponsored by an agency of the United States Government. Neither the United States Government nor any agency thereof, nor any of their employees, makes any warranty, express or implied, or assumes any legal liability or responsibility for the accuracy, completeness, or usefulness of any information, apparatus, product or process disclosed, or represents that its use would not infringe privately owned rights. Reference herein to any specific commercial product, process or service by trade name, trademark, manufacturer, or otherwise does not necessarily constitute or imply its endorsement, recommendation, or favoring by the United States Government or any agency

thereof. The views and opinions of authors expressed herein do not necessarily state or reflect those of the United States Government or any agency thereof.

This report has been reproduced directly from the best available copy.

Available for sale to the public, in paper, from: U.S. Department of Commerce, National Technical Information Service, 5285 Port Royal Road, Springfield, VA 22161, phone: (800)

553-6847, fax: (703) 605-6900, email: orders@ntis.fedworld.gov online ordering: http://www.ntis.gov/ordering.htm

Available electronically at http://www.doe.gov/bridge

Available for a processing fee to U.S. Department of Energy and its contractors, in paper, from: U.S. Department of Energy, Office of Scientific and Technical Information, P.O. Box 62, Oak Ridge, TN 37831-0062, phone: (865 ) 576-8401, fax: (865) 576-5728, email: reports@ adonis.osti.gov 
WSRC-TR-2000-00469

SRT-RPP-2000-00043

Revision 1

\section{SUMMARY}

A radioactive sample $(\sim 15 \mathrm{~L})$ from Hanford tank 241-AN-102 was concentrated from 4.9 $\mathrm{M}$ to $7.1 \mathrm{M} \mathrm{Na}$ via evaporation at $50^{\circ} \mathrm{C}$ and $9.5 \mathrm{kPa}$ (71 torr) to support flowsheet development and regulatory approval for the Hanford River Protection Project Waste Treatment Plant (RPP-WTP). The received sample (Envelope C) had been pretreated at the Savannah River Technology Center (SRTC) for removal of strontium and transuranic ions by precipitation and removal of cesium and technetium via ion exchange. The operating pressure and steady-state concentration were specified by an OLI Environmental Simulation Program (ESP) model and mimicked the planned operating conditions for the low-activity waste (LAW) melter feed evaporator in the RPP-WTP.

Under these prototypic conditions, significant foaming occurred. Dow 1520-US antifoam, primarily made of polydimethylsiloxane, was added at $1 \mathrm{~g} / \mathrm{L}$ every 2-3 hours and effectively minimized foaming. Scaling was not observed.

During steady-state operation, three different EPA SW-846 offgas sampling methods were used: volatiles (Method 0031), metals/radionuclides (Method 0060), and semivolatiles (Method 0010), in that order. The offgas stream passed through either resin beds or liquid solutions, depending on the prescribed method. The resulting offgas samples, along with many liquid samples of concentrate, condensate, and their associated process blanks, field blanks, reagent blanks, and trip blanks, were shipped offsite to be analyzed at a laboratory that routinely performs analyses according to EPA SW-846 (i.e., regulatory) protocol. Regulatory results will be reported in a separate document. ${ }^{1}$ SRTC analyzed the feed, concentrate and condensate liquid samples that are presented here.

During steady-state operation, $0.3 \mathrm{wt} . \%$ insoluble sodium oxalate solids were observed in the concentrate, which was consistent with model predictions. The final boildown demonstrated a dramatic solubility endpoint at $\sim 8.2 \mathrm{M} \mathrm{Na}$, changing from $2 \%$ to $16 \%$ insoluble solids in a few minutes. The major precipitant at the endpoint was identified by $\mathrm{XRD}$ as sodium carbonate hydrate.

Approximately 7.5 liters of concentrated AN102 evaporator product served as the feed material for a melter vitrification study conducted at SRTC. ${ }^{2}$ The RPP-WTP design has the offgas from this LAW Melter system recycled into evaporator feed. These experiments did not include this recycle stream, which contains insoluble salts and glass formers. ${ }^{3}$ It is recommended that future evaporation studies include simulated or actual recycle streams.

\footnotetext{
${ }^{1}$ Ferrara, D.M., C.L. Crawford, M.L. Crowder, H.H. Saito, and T.B. Calloway, Sample Analysis Results for a Benchscale Evaporator Test Using Envelope C Feed, WSRC-TR-2000-00469, SRT-RPP-200000043, Westinghouse Savannah River Company, Aiken, SC, in press.

${ }^{2}$ Hutson, N.D., J.R. Zamecnik, R.L. Minichan, P.R. Burket, C.L. Crawford, T.L. Fellinger, D.T. Herman, J.G. Wheeler, Vitrification of Pretreated Large C (AN-102) Sample - Preliminary Status Report, SRTRPP-2001-00009, Westinghouse Savannah River Company, Aiken, SC, Jan. 15, 2001.

${ }^{3}$ Calloway, T. B., Jr. and M. E. Summer, Characterization of Melter Off Gas Condensate from the Duratek LAW Pilot Melter Off Gas System, BNF-003-98-0281, Westinghouse Savannah River Company, May $19,2000$.
} 
WSRC-TR-2000-00469

SRT-RPP-2000-00043

\section{TABLE OF CONTENTS}

Revision 1

SUMMARY .2

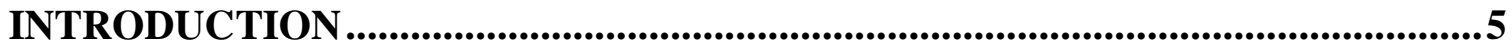

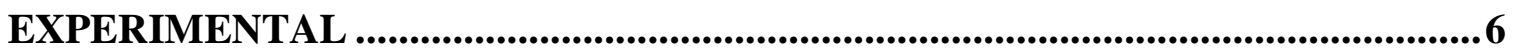

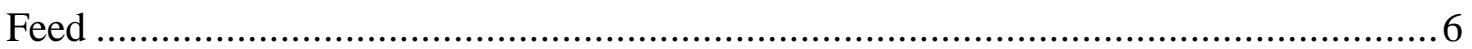

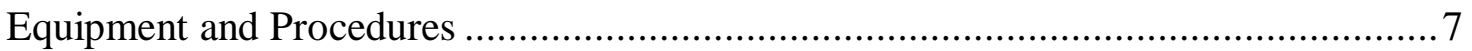

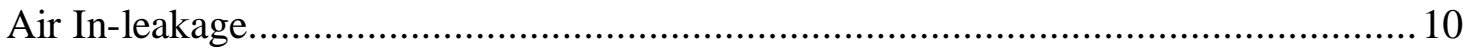

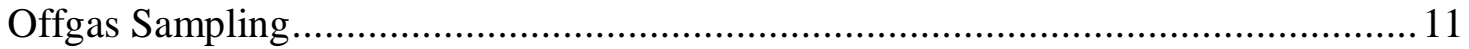

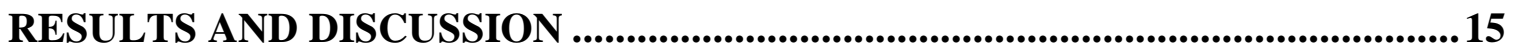

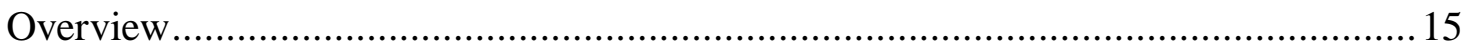

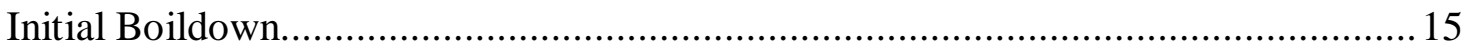

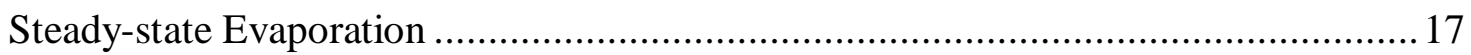

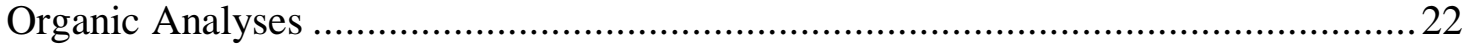

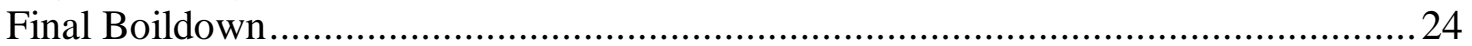

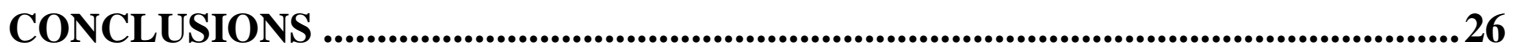

ACKNOWLEDGMENTS ....................................................................................227

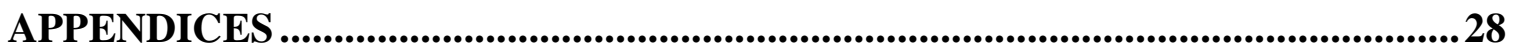

Appendix A: Description of SW-846 Methods.............................................. 28

Appendix B: Analytical Results for Feed, Concentrate, and Condensate ................... 30

Appendix C: Organic Analyses ........................................................... 40

\section{LISTS OF TABLES AND FIGURES}

Table 1. Typical Steady-state Operating Conditions for LAW Evaporator .................... 8

Table 2. System Air In-leakage Comparison............................................................. 11

Table 3. Overall Material Balance for Envelope C Evaporation ................................. 18

Table 4. Sodium Concentration in Evaporator Products ............................................. 19

Table 5. AN102 Evaporation - Elemental and Isotopic Analyses with

Concentration and Decontamination Factors (CF and DF) .............................20

Table 6. AN102 Evaporation - Analysis of Feed, Concentrate and Condensate ............21

Table 7. Volatile (VOC) Results for Envelope C Evaporation Products ........................22

Table 8. Semivolatile (SVOC) Results for Envelope C Evaporation Products ............... 23

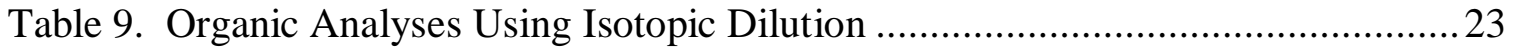

Table 10. Analytical Results for Final Boildown Samples...........................................25

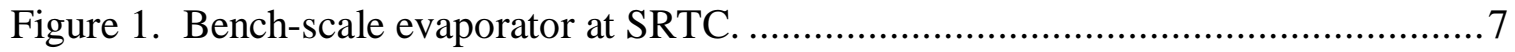

Figure 2. Sampling apparatus for Volatile Organic Analysis of offgas. ........................ 12

Figure 3. Offgas sampling equipment for capture of organic compounds.................... 13 
WSRC-TR-2000-00469

SRT-RPP-2000-00043

Revision 1

Figure 4. Jacketed impingers for capture of offgas metals............................................. 14

Figure 5. Operating conditions during initial boildown of Envelope C......................... 15

Figure 6. Foaming observed during evaporation of Envelope C (AN102).....................16

Figure 7. Steady-state operating conditions for Large $\mathrm{C}$ evaporation.............................. 17

Figure 8. Samples 1-8 from final boildown (in numerical and

chronological order, from left to right) 
WSRC-TR-2000-00469

SRT-RPP-2000-00043

Revision 1

\section{INTRODUCTION}

The baseline low activity waste (LAW) flow sheet for the River Protection Project (RPP) Waste Treatment Plant (WTP) includes pretreatment of Envelope A, B, and C supernate by removing strontium and transuranic ions via precipitation and cesium and technetium ions via ion-exchange. This pretreated LAW is concentrated in an evaporator. Then, glass formers are added and the resulting slurry is fed to joule-heated, refractory-lined melters that are designed to operate nominally at $1,150^{\circ} \mathrm{C}$. The design goals of the pretreated LAW evaporator are to maximize the waste loading in the melter feed by removing as much water as possible without over-concentrating the slurry to the point that (1) the material cannot be transported to the melter, and (2) that inadequate distribution of the feed on the melt surface hinders the melting process. To preclude the formation of solids during the storage of evaporator products, the RPP-WPT contractor has set additional criteria for limiting the concentration of the evaporator bottoms to $80 \%$ saturation at $25^{\circ} \mathrm{C} .^{4}$

The design of the RPP-WTP evaporators is based upon the Hanford 242-A evaporator that is used to concentrate Hanford supernate wastes. ${ }^{5,6}$ The Hanford 242-A evaporator is a forced-circulation evaporator that is designed to operate at an absolute pressure of 40 to 80 torr. ${ }^{7}$ During Part A of the Tank Waste Remediation System (TWRS) Privatization contract, Savannah River Technology Center (SRTC) personnel evaporated the Hanford LAW melter feed in crucibles at atmospheric pressure. However, no attempt was made during Part A to demonstrate the LAW melter feed evaporator unit operation.

As part of the WSRC Part B1 contract, SRTC performed a series of small-scale scouting evaporation experiments using simulants of Envelope A, B and $\mathrm{C}^{8}$ to determine the solubility limits of these simulants at temperatures ranging from 50 to $100^{\circ} \mathrm{C}\left(100^{\circ} \mathrm{C}\right.$ for Envelope A only). ${ }^{9}$ The contract also included a series of bench-scale evaporator runs to be conducted at $50^{\circ} \mathrm{C}$. The data from both solubility and bench-scale evaporation tests are to be used to validate the steady-state evaporator model developed using an OLI Systems Environmental Simulation Program (ESP). The details and results of previous solubility and bench-scale evaporator experiments and modeling are outlined elsewhere. ${ }^{9,10,11}$

${ }^{4}$ BNFL Letter No. 000623, TWRS-P Contract No. DE-AC06-96RL13308 - W375 - LAW Evaporator Modeling, Michael E. Johnson to Steven T. Wach, Feb. 16, 1999.

${ }^{5}$ Kalra, S., System Description - System PT-130 LAW Melter Feed Evaporator, SD-W375PT-PR000014 Rev. 0, BNFL Inc., Richland WA, Nov. 8, 1999.

${ }^{6}$ Verbal Conversation with M. E. Johnson concerning LAW Melter Feed Evaporator, Jan. 19, 1999.

${ }^{7}$ Guthrie, M.D., 242-A Evaporator Campaign 97-1 Post Run Document, HNF-SD-WM-PE-057, Waste Management Hanford, Richland, WA 99352, Aug. 15, 1997.

${ }^{8}$ Tanks 241-AN-105, AZ-101 and AN-107, respectively were used as the basis for the Envelope A, B, and C simulants.

${ }^{9}$ Monson, P.R., Envelopes A, B and C Shaker/Bath Evaporation Saturation Studies, BNFL-003-98-0189 (SRT-PTD-99-0062) Rev. 0, Westinghouse Savannah River Company, Jan. 4, 2000.

${ }^{10}$ Calloway, T.B., A.S. Choi, and P.R. Monson, Evaporation of Hanford Envelope B Simulant (AZ-101) Preliminary Report, BNF-003-98-0166 Rev. 1, Westinghouse Savannah River Company, Jan. 6, 2000. 
WSRC-TR-2000-00469

SRT-RPP-2000-00043

Revision 1

The principal objectives of these tasks (Solubility Studies, Bench Scale Evaporation, and Evaporation Modeling) are to determine the following:

- Bulk Solubility

- Major precipitating species

- Expected evaporator operating parameters (temperature, pressure)

- Composition of the evaporator concentrate and condensate

- Physical properties of the concentrate (e.g., density and solids content)

- Extent of foaming and scaling during the evaporation

This report contains the results of the Bench Scale evaporation of a large ( $\sim 15 \mathrm{~L})$ sample of pretreated Envelope C (AN102). Technical guidance and quality assurance requirements for this study are documented separately. ${ }^{12}$

\section{EXPERIMENTAL}

\section{Feed}

The evaporator feed originated from Hanford tank 241-AN-102. The AN102 tank sample was diluted, characterized, and decontaminated using the reference RPP-WPT pretreatment precipitation and ion exchange processes. The resulting decontaminated AN102 sample was used for this experiment. The pre-fix "241" is common to all Hanford underground storage tanks and is not used further in this report. The major components of the feed are included in Table 5 and Table 6 of the Results section for comparison with evaporator products. The feed contained 4.85 $\mathrm{M}$ sodium (Na), a component used for determining waste loading in the melter feed. Unless otherwise stated, SRTC performed all chemical analyses in this report.

A component added to the concentrate during processing was an antifoam agent, DOW Corning 1520-US Batch No. 0000235. This antifoam is primarily made of polydimethylsiloxane. For this study, it was also tested for trace organics. The antifoam-to-evaporator feed ratio used for these experiments was one gallon of antifoam per 1,000 gallons of evaporator feed $\left(1 \mathrm{~g}\right.$ antifoam/L). ${ }^{13}$ This basis is not dependent on the specific gravity of the evaporator feed.

\footnotetext{
${ }^{11}$ Choi, A.S., Preliminary Modeling Results of Pretreated LAW Evaporator, BNF-003-98-0080 Rev. 0, Westinghouse Savannah River Company, June 1, 1999.

${ }^{12}$ Crowder, M.L., T. Bond Calloway, Jr., and C.L. Crawford, Task Technical and Quality Assurance Plan for Bench Scale LAW Evaporation of a Pretreated Large Envelope C (AN102) Hanford Sample, BNF003-98-0242 Rev. 0, Westinghouse Savannah River Company, July 17, 2000.

${ }^{13}$ Verbal conversation (\& email) with Elvis Q. Le, Lockheed Martin Hanford Company 242-A Evaporator Process Engineering, May 24, 1999.
} 
WSRC-TR-2000-00469

SRT-RPP-2000-00043

Revision 1

Equipment and Procedures

Figure 1 shows a diagram of the bench-scale evaporator unit. The evaporator pot was designed based upon a natural-circulation calandria (thermosiphon reboiler). Thermosiphon evaporators operate by density differences between the liquid entering the heat exchanger and the two-phase vapor-liquid mixture that is generated in and exits the heat exchanger. ${ }^{14}$ The design of this experimental rig was based upon the experimental design detailed in reference 15. The operating pressure of the RPP-WPT evaporator coupled with the constraints of laboratory hoods dictated use of this design. The liquid in the evaporator is mixed with a magnetic stirrer. To increase flow to the heater, the liquid lines between the evaporator and the heater are mounted tangentially to the mixing of the solution inside the evaporator.

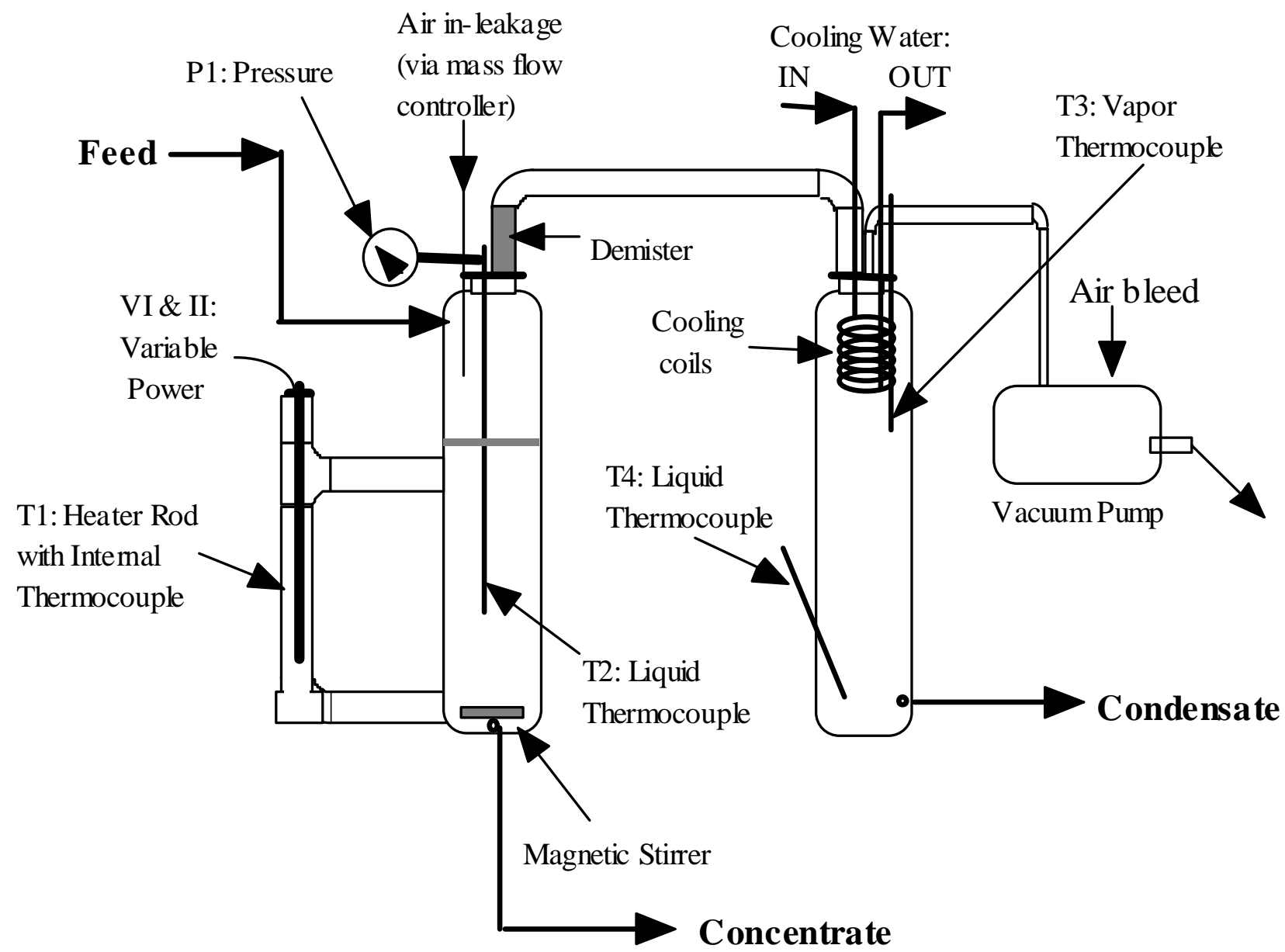

Figure 1. Bench-scale evaporator at SRTC.

${ }^{14}$ Minton, Paul E., Handbook of Evaporation Technology, Noyes Publications, Mill Rd. Park Ridge, NJ, Library of Congress 86-17978, 1986.

${ }^{15}$ Nash, C.A., Task Technical and Quality Assurance Plan for the CIF Bench Evaporator (U), WSRC-RP98-00328 Rev. 1, Westinghouse Savannah River Company, Aiken, SC, Sep. 18, 1998. 
WSRC-TR-2000-00469

SRT-RPP-2000-00043

Revision 1

The evaporator and condenser were constructed of sodium borosilicate glass tubing (100 $\mathrm{mm}$ dia.). These vessels had volumes of approximately 2.2 to $2.5 \mathrm{~L}$. The evaporator and condenser volumes were calibrated with deionized water prior to the experiment and were marked to the nearest $100 \mathrm{~mL}$. Peristaltic pumps were used to add feed to the system and to withdraw concentrate and condensate from the system. Teflon ${ }^{\circledR}$ tubing was used for all liquid transfer lines and Viton ${ }^{\circledR}$ tubing was used for the peristaltic pumps. Teflon $^{\circledR}$ and Viton ${ }^{\circledR}$ were also used, instead of vacuum grease, to seal system parts and glass joints together. These materials were chosen for their chemical/corrosion resistance and minimal sorption/desorption characteristics.

The evaporator was heated using a corrosion and oxidation resistant Incoloy ${ }^{\circledR} 1000 \mathrm{~W}$ resistance heater. The heater had an internal thermocouple that gave a reasonable approximation of the heater surface temperature. The temperature difference between the heater surface and the evaporator pot gave a secondary indication of scaling on the heat transfer surface. The primary indication of scaling was visual. The following system parameters were measured throughout the experiment:

- Heater Voltage and Current (VI \& II)

- Heater Surface Temperature (T1)

- Evaporator Temperature and Pressure (T2, P1)

- Condenser Temperature (T3)

- Condensate Hold Tank Temperature (T4)

- Condenser Chiller Temperature

- Vessel Volumes

- Evaporator Feed and Discharge Flow Rates

A list of typical values for steady-state evaporator operation is provided below. These conditions were observed at 0100 hours on July 22, 2000, during the last phase of testing. Shortly after this, feed and concentrate pump rates were adjusted to stabilize the mass balance.

Table 1. Typical Steady-state Operating Conditions for LAW Evaporator

\begin{tabular}{|c|c|c|c|c|c|c|c|}
\hline $\begin{array}{c}\text { VI } \\
\text { volts }\end{array}$ & $\begin{array}{c}\text { II } \\
\text { amps }\end{array}$ & $\begin{array}{c}\mathrm{T} 1 \\
{ }^{\circ} \mathrm{C}\end{array}$ & $\begin{array}{c}\mathrm{T} 2 \\
{ }^{\circ} \mathrm{C}\end{array}$ & $\begin{array}{c}\mathrm{P} 1 \\
\text { in. } \mathrm{Hg}\end{array}$ & $\begin{array}{c}\mathrm{T} 3 \\
{ }^{\circ} \mathrm{C}\end{array}$ & $\begin{array}{c}\mathrm{T} 4 \\
{ }^{\circ} \mathrm{C}\end{array}$ & $\begin{array}{c}\text { Air in-leakage } \\
\mathrm{mL} / \mathrm{min}\end{array}$ \\
\hline 41 & 3.32 & 67.2 & 51.1 & -26.9 & 40.2 & 33.6 & 11.5 \\
\hline
\end{tabular}

\begin{tabular}{|c|c|c|c|c|}
\hline $\begin{array}{c}\text { Evaporator } \\
\text { Level } \\
\mathrm{mL}\end{array}$ & $\begin{array}{c}\text { Condenser } \\
\text { Level } \\
\mathrm{mL}\end{array}$ & $\begin{array}{c}\text { Feed } \\
\text { Pump Rate } \\
\mathrm{mL} / \mathrm{min}\end{array}$ & $\begin{array}{c}\text { Concentrate } \\
\text { Pump Rate } \\
\mathrm{mL} / \mathrm{min}\end{array}$ & $\begin{array}{c}\text { Condensate } \\
\text { Production Rate } \\
\mathrm{mL} / \mathrm{min}\end{array}$ \\
\hline 1500 & 510 & 6 & 4 & 2.4 \\
\hline
\end{tabular}


WSRC-TR-2000-00469

SRT-RPP-2000-00043

Revision 1

The bench scale evaporation experiment was conducted as a "Process Simulation." That is, given the scale of the system and the budget and schedule constraints, every effort was made to operate the system as closely to the full-scale unit as possible. Therefore, to the extent possible, the experimental procedure followed the normal operation of a forced circulation evaporator.

The bench-scale evaporator was initially charged with approximately $1.5 \mathrm{~L}$ of Envelope $\mathrm{C}$ feed with a specific gravity of $1.23 \mathrm{~g} / \mathrm{ml}$. The system pressure was maintained at 9.55 $\pm 0.10 \mathrm{kPa}(71.6 \pm 0.8$ torr, $-27.1 \pm 0.3 \mathrm{in}$. $\mathrm{Hg}$ gauge $)$. This pressure was calculated by the SRTC LAW Evaporator OLI ESP model, and represented the steady-state operating pressure required at $50^{\circ} \mathrm{C}$ to reach the desired evaporation endpoint. The condenser temperature was maintained at $40 \pm 3^{\circ} \mathrm{C}$ which is the design basis temperature for the RPP-WPT pretreated LAW evaporator. The heat flux through the heater rod was maintained at 6.0 to $6.3 \mathrm{~W} / \mathrm{cm}^{2}$ during the steady-state portions of the experiment, and scaling was monitored visually. This heat flux represents about $75 \%$ of the design basis for the RPP LAW Melter Feed Evaporator $\left(8.13 \mathrm{~W} / \mathrm{cm}^{2}\right)$.

System vacuum was maintained using an oil-free PTFE diaphragm vacuum pump that was capable of an ultimate vacuum of 9 torr. The vacuum pump was connected to the system with 304-L stainless steel tubing and Teflon ${ }^{\circledR}$ tubing. To minimize entrainment, the overhead tube between the evaporator and condenser had a "J"-shaped inlet port and was packed with stainless steel mesh, according to an earlier design. ${ }^{16}$

Once the initial batch of salt solution began to boil, it was allowed to concentrate to a predetermined endpoint, selected by the RPP customer as $80 \%$ of the bulk solubility at $25^{\circ} \mathrm{C}$. The bulk solubility is the concentration, as defined by the mass of total solids in $100 \mathrm{~g}$ of $\mathrm{H}_{2} \mathrm{O}$, where one of the major salt species begins to precipitate. A major precipitating species is defined by the RPP customer as a compound that becomes insoluble and forms in excess of $0.1 \mathrm{wt} . \%$ of the total solution. The ESP model used for this experiment predicted that the feed at $25^{\circ} \mathrm{C}$ would include a small quantity ( $\sim 0.04$ wt. $\%$ ) of insoluble solids, mostly as sodium oxalate, $\mathrm{Na}_{2} \mathrm{C}_{2} \mathrm{O}_{4}$, and some as nickel hydroxide, $\mathrm{Ni}(\mathrm{OH})_{2}$. The model predicted the double salt, $\mathrm{Na}_{7} \mathrm{~F}\left(\mathrm{PO}_{4}\right)_{3} \bullet 19 \mathrm{H}_{2} \mathrm{O}$, to precipitate out next at $8.5 \mathrm{M} \mathrm{Na}^{17}$ To operate the evaporator at $80 \%$ solubility, the target steady-state concentration for this experiment was 7.1 $\mathrm{M} \mathrm{Na}$, which corresponds to the following predicted properties at $\left.25^{\circ} \mathrm{C}: 1\right)$ specific gravity $=1.325 ; 2$ ) insoluble solids = 0.16 wt. $\%$ as $\mathrm{Na}_{2} \mathrm{C}_{2} \mathrm{O}_{4}$ and $\mathrm{Ni}(\mathrm{OH})_{2} .{ }^{17}$

Once the endpoint concentration was reached during the initial boildown, the steadystate ${ }^{18}$ portion of the experiment was started. During steady-state evaporation, the evaporator feed pump and discharge pumps were started, and their flow rates were set

\footnotetext{
${ }^{16}$ Saito, H.H., T.B. Calloway, D.M. Ferrara, A.S. Choi, T.L. White, L.V. Gibson, and M.A. Burdette, AN107 (C) Simulant Bench-Scale LAW Evaporation with Organic Regulatory Analysis, WSRC-TR-200000486 (SRT-RPP-2000-00047, BNF-003-98-0275), Westinghouse Savannah River Co., Feb. 2001.

${ }^{17}$ Choi, A.S., personal communication, June 27, 2000.

${ }^{18}$ Steady-state conditions are defined as maintaining a constant evaporator level (and therefore the Evaporator concentrate composition) at constant pressure and temperature.
} 
based on the measured condensate rate and desired concentrate concentration. System properties, which included temperature, pressure, and liquid levels were recorded every fifteen minutes. The nominal condensate production rate was approximately $3.0 \mathrm{~g} / \mathrm{min}$. A simple mass balance was used to predict the evaporator feed and discharge rates, yielding nominal values of 10.0 and $7.0 \mathrm{ml} / \mathrm{min}$, respectively. These flow rates were set to maintain a constant liquid level in the evaporator and a constant composition of the concentrate. When the condensate production rate decreased during operation, the feed and concentrate flow rates were also reduced accordingly.

The unit was operated under steady-state conditions for three ten-hour segments, each corresponding to a different offgas sampling method: volatiles, metals/radionuclides, and semivolatiles, sampled in that order. The evaporator was shut down between these tenhour segments to facilitate sampling, change of offgas sampling equipment, and drainage of the condenser. Concentrate samples were taken periodically during the volatiles offgas sampling portion of the experiment and submitted for regulatory and in-house analysis. Two 1-L samples of concentrate from the semivolatiles portion of the experiment were submitted for multiple regulatory analyses. The remaining concentrate from different portions of the experiment was combined to provide feed for the LAW Melter for vitrification. Feed, concentrate, condensate, and offgas samples were submitted for various physical and chemical analyses. A detailed listing of the sampling and analytical plans can be found elsewhere. ${ }^{19,20}$

\section{Air In-leakage}

To simulate the amount of air leakage into the RPP-WPT design basis evaporator, ${ }^{21} \mathrm{a}$ simple calculation was performed and is shown in Table 2. To match the design air inleakage rate of $16.8 \mathrm{~kg} / \mathrm{hr}$, the prescribed air in-leakage for the bench scale evaporator is $8.26 \times 10^{-4} \mathrm{~kg} / \mathrm{hr}$; this corresponds to $11.5 \mathrm{~mL} / \mathrm{min}$ at room temperature and pressure. To meet this requirement, the experimental apparatus was made as airtight as possible and an air line fed from a mass flow controller was inserted into the evaporator vapor space.

Natural system air in-leakage was measured before the experiment by conducting a standard air in-leakage test for vacuum systems. ${ }^{22}$ The test is based on the fact that air leaks into the system at a constant rate as long as the pressure in the system is less than 0.53 times atmospheric pressure ( 400 torr). To simulate experimental conditions, the

${ }^{19}$ Crowder, M.L., T. Bond Calloway, Jr., and C.L. Crawford, Task Technical and Quality Assurance Plan for Bench Scale LAW Evaporation of a Pretreated Large Envelope C (AN102) Hanford Sample, BNF003-98-0242 Rev. 0, Westinghouse Savannah River Company, Aiken SC, July 17, 2000.

${ }^{20}$ Ferrara, D.M., R.S. Groseclose, R.J. Ray, C.L. Crawford, and T. Bond Calloway, Jr., Task Technical, Analytical Study, and Quality Assurance Plan in Support of BNFL Part B: "Regulatory" Sample Analyses from A, B, C, LC, and HLW Studies at SRTC, BNF-003-98-0082, Rev. 0, Westinghouse Savannah River Company, Jan. 7, 1999.

${ }^{21}$ Ho, J. and M. Washer, CALC-W375PT-PR00011, Rev. 1, Stage B - Air Inleakage into LAW Pretreatment Evaporation Systems, Oct. 27, 1999.

${ }^{22}$ Standards for Steam Jet Ejectors 3rd Edition, Heat Exchanger Institute 122 East $42^{\text {nd }}$ St New York, NY, $3^{\text {rd }}$ Edition, 1956. 
WSRC-TR-2000-00469

SRT-RPP-2000-00043

Revision 1

test was run with liquid "heels" of about $150 \mathrm{~mL}$ in the evaporator and condenser with the rest of the system empty. An accurate measurement of the total system volume (5200 $\mathrm{mL}$ ) and the pressure rise over a measured time duration showed only a $0.3 \mathrm{~mL}$ air $/ \mathrm{min}$ natural air in-leakage into the system. Thus, the mass flow controller was set to 11.2 $\mathrm{mL} / \mathrm{min}$ throughout the experiment.

Table 2. System Air In-leakage Comparison

\begin{tabular}{|l|c|c|c|c|}
\hline \multicolumn{1}{|c|}{ System } & $\begin{array}{c}\text { System Volume } \\
\left(\mathrm{m}^{3}\right)\end{array}$ & \multicolumn{2}{|c|}{$\begin{array}{c}\text { Air In-leakage } \\
(\mathrm{kg} / \mathrm{hr})\end{array}$} & $\begin{array}{c}\text { Leak Volume (1 hour) } \\
\text { System Volume }\end{array}$ \\
\hline $\begin{array}{l}\text { RPP-WPT } \\
\text { Pretreated LAW } \\
\text { Evaporator }\end{array}$ & $\sim 104$ & 16.8 & 233 & 0.13 \\
\hline $\begin{array}{l}\text { Bench Scale } \\
\text { Evaporator }\end{array}$ & $5.2 \times 10^{-3}$ & $0.826 \times 10^{-3}$ & $11.5 \times 10^{-3}$ & 0.13 \\
\hline
\end{tabular}

Downstream of the evaporator and vacuum pump, an air bleed valve was added to the vacuum pump exhaust. This allowed an increase in the total air volume flowing into the offgas sampling equipment, which works best at a flow rate of 0.5 to $1.0 \mathrm{~L} / \mathrm{min}$. Hence, offgas analytical results must take into account this dilution of $11.5 \mathrm{~mL} / \mathrm{min}$ of actual sample compared to $\sim 0.5 \mathrm{~L} / \mathrm{min}$ total sample processed.

\section{Offgas Sampling}

The offgas sampling equipment conformed to SW-846 methods issued by the U.S. Environmental Protection Agency (EPA). Descriptions of the methods are provided in Appendix A, and full methods are available from the EPA. Highlights are included here. Since SW-846 methods were designed for industrial stack gases, the volumes required were higher than could be obtained with our apparatus, design constraints, and feed volume. Sample volumes for this study totaled approximately $7 \mathrm{~L}$. In addition, bleed air was added to stabilize system operation. Thus, the total volume of gas that passed through the sampling system was on the order of $280 \mathrm{~L}$ for each method. SW-846 requirements for sample volume are typically $20 \mathrm{~L}$ for volatile organics. Method 0010 (semivolatiles) requires 3 dry standard cubic meters. Method 0060 typically collects 1.25 to 5 dry standard cubic meters.

As mentioned above, the first steady-state portion of the experiment involved sampling for volatile compounds. The third portion of the experiment involved sampling for semivolatiles, defined as compounds with boiling points greater than $105^{\circ} \mathrm{C}$. For these two experimental segments, the basic equipment used was the same. The only difference was the type of absorbent resins. A diagram of the sampling apparatus for capturing volatiles is provided in Figure 2. A photograph of the semivolatiles sampler is shown in Figure 3. In both sets of organics, an Apex Model 602-V31 Super VOST (Volatile Organic Sampling Train) Sampling Kit (on the left in Figure 3) was coupled with a 
WSRC-TR-2000-00469

SRT-RPP-2000-00043

Revision 1

Model 623 Metering Console. For volatiles, SW-846 Method 0031 was used, which is sometimes referred to as VOA (Volatile Organic Analysis). For capturing volatile organic compounds, two resin tubes containing Tenax ${ }^{\circledR}-\mathrm{GC}$ and one containing Anasorb $^{\circledR}-747$ (Rohm and Haas) were used. For the semivolatile (SVOA) portion of the experiment, one resin tube containing XAD- 2 was used. In both cases, the offgas initially passed through a condenser maintained at $10^{\circ} \mathrm{C}$ before passing through the resin tubes. In addition, a tube of activated carbon and a HEPA-quality in-line filter were attached after the sampling tubes to prevent the release of organic constituents and radionuclide particulates into the atmosphere.

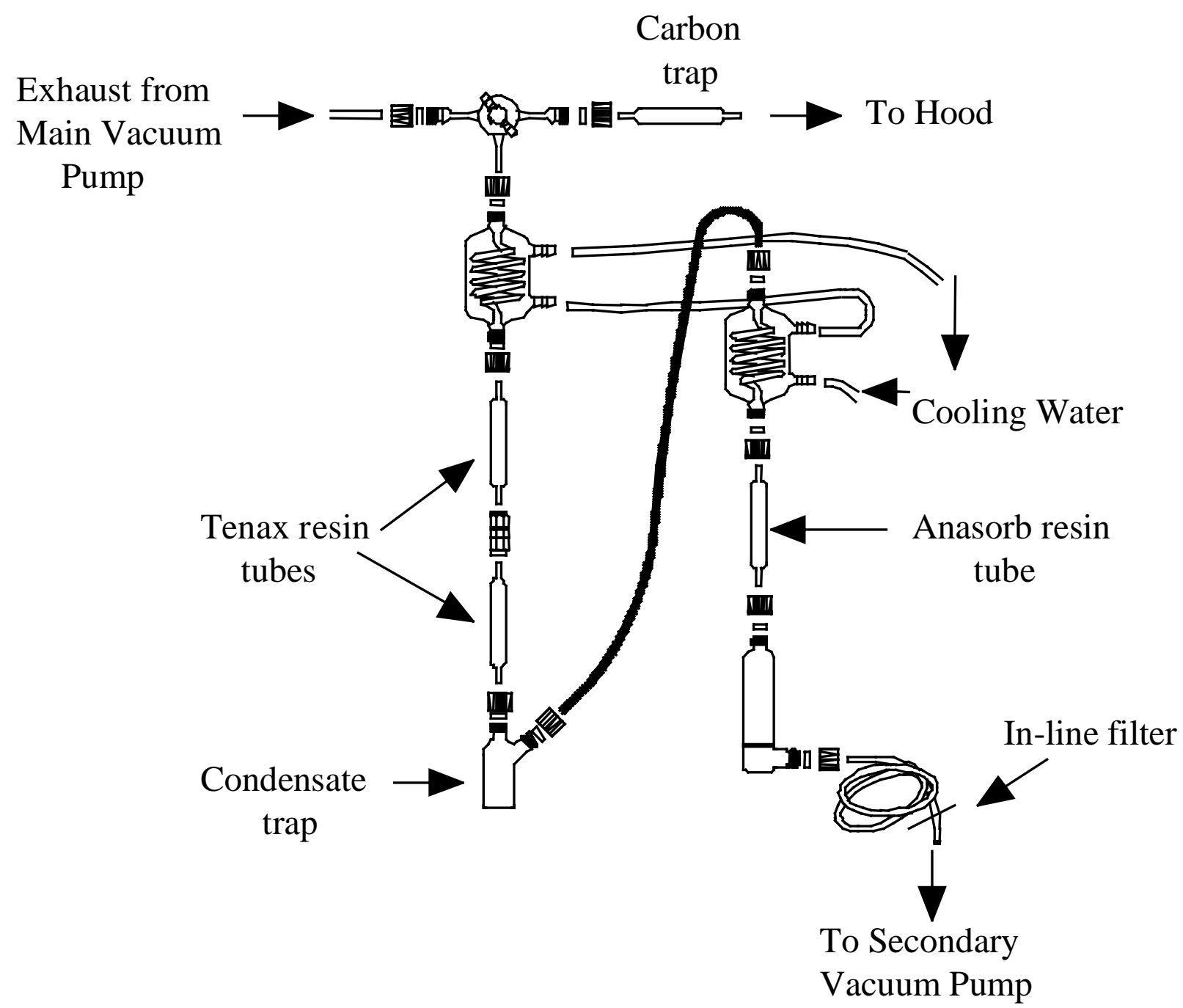

Figure 2. Sampling apparatus for Volatile Organic Analysis of offgas. 
On the right side of Figure 3 is the gas metering console used to monitor offgas sampling. The pressure in the offgas sampling line was maintained at a few inches of water below atmospheric pressure. The system was leak checked prior to each sampling period, both for actual samples and beforehand for process blanks. Also, the flow meter in the console was calibrated with a DryCal ${ }^{\mathrm{TM}}$ NIST-traceable flow meter before and after the experiment as a standard quality check of the data.

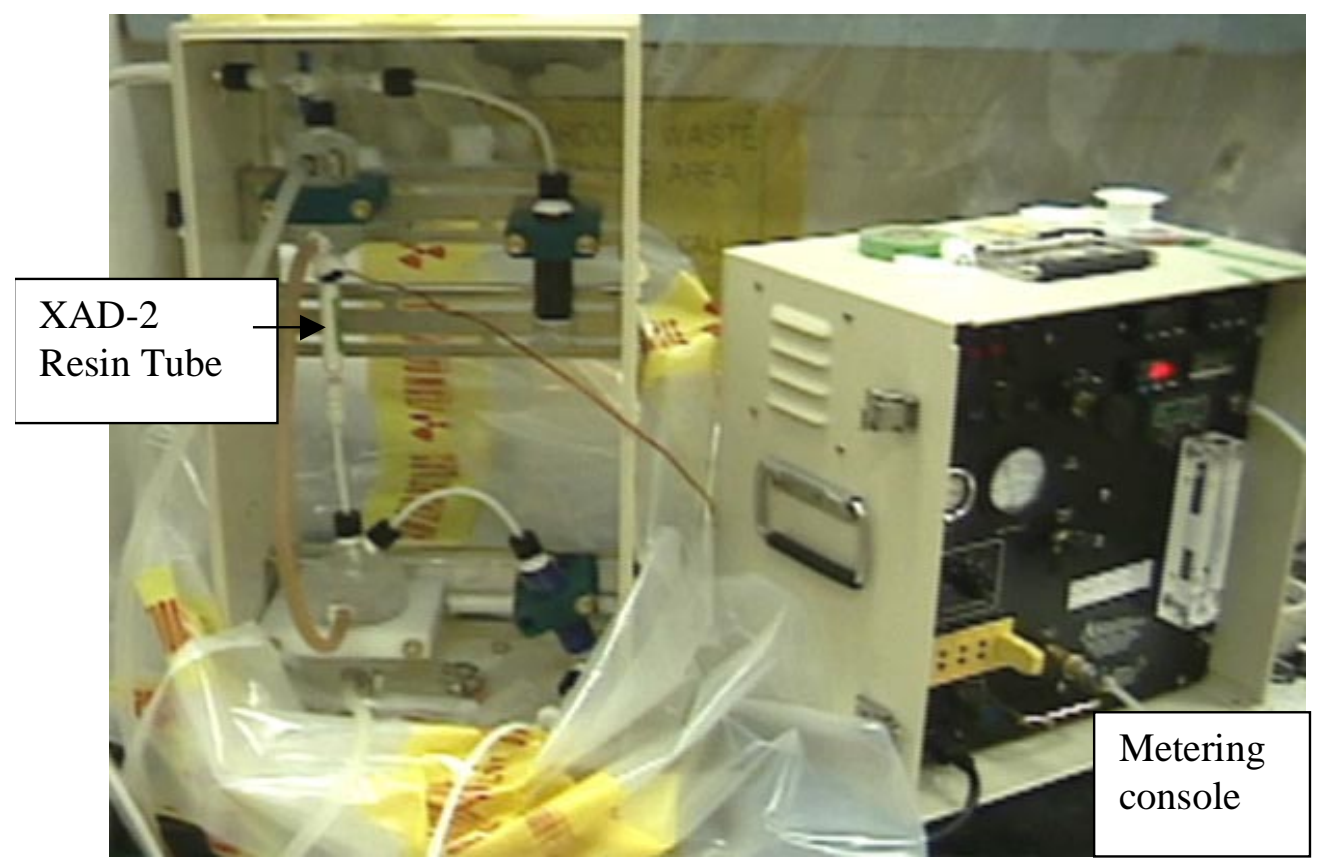

Figure 3. Offgas sampling equipment for capture of organic compounds.

For analysis of offgas metals and radionuclides using Method 0060, jacketed impingers were made at SRTC. Figure 4 shows the impingers before the experiment. As described in the Task Plan, the impingers were kept cool with circulating cold water at $10^{\circ} \mathrm{C}$. The first impinger (on the left) was empty, and was used for moisture knockout. The second and third impingers were half full, containing an aqueous solution of $5 \% \mathrm{HNO}_{3}, 10 \%$ $\mathrm{H}_{2} \mathrm{O}_{2}$. The fourth impinger was empty to prevent carry over between solutions. The fifth and sixth impingers were half full with $4 \% \mathrm{KMnO}_{4}$ and $10 \% \mathrm{H}_{2} \mathrm{SO}_{4}$ for capture of mercury. Reagent grade chemicals and deionized water were used to make the solutions, with the same water used for both blanks and samples. The seventh impinger was filled with silica gel desiccant. The large impinger shown in the right of Figure 4 was not used in the experiment, since a large amount of desiccant in the final impinger was not needed. All impingers were weighed before and after the experiment to determine moisture gain (or loss). 


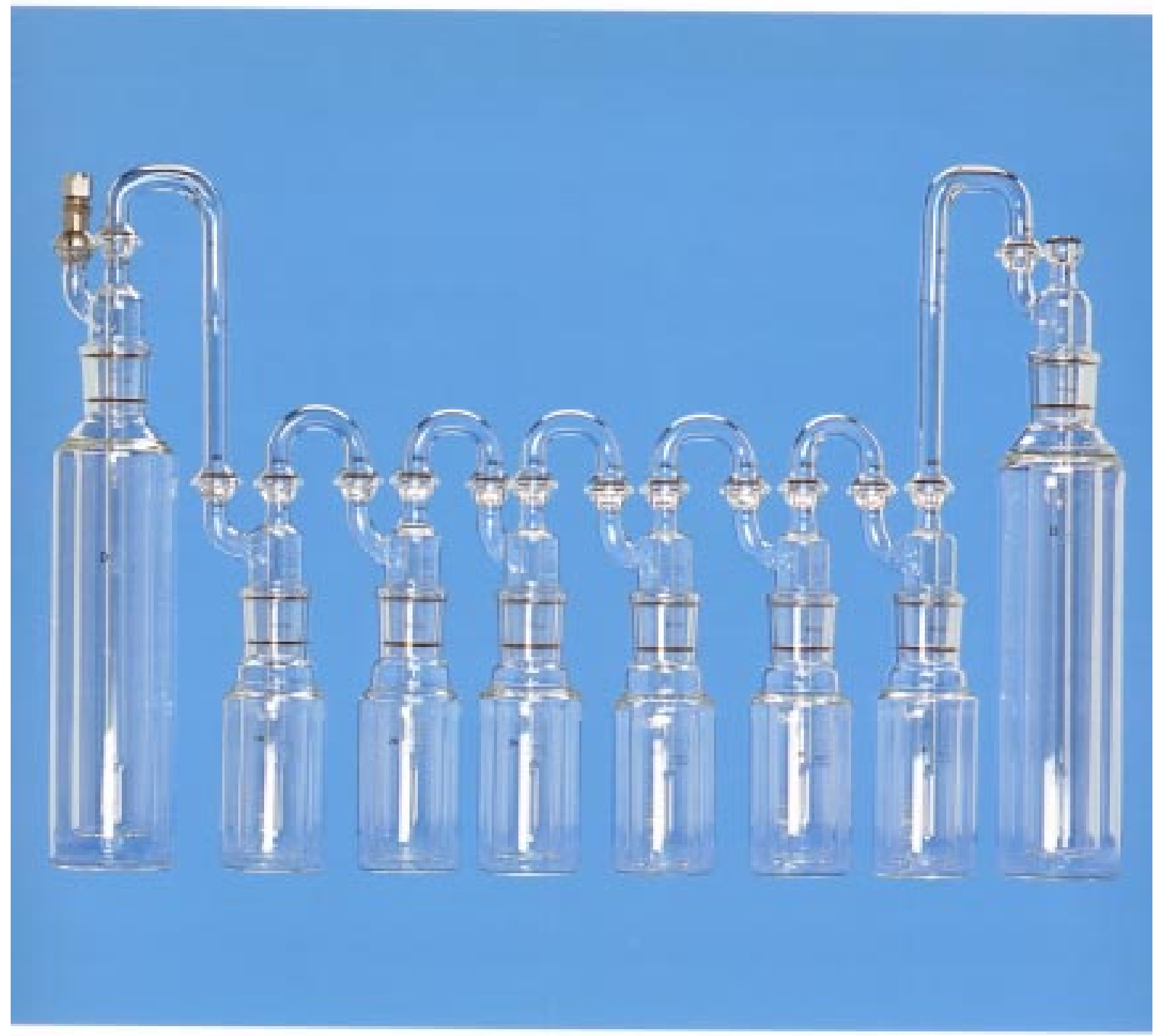

Figure 4. Jacketed impingers for capture of offgas metals.

Results of the regulatory analyses done using EPA SW-846 methods, i.e., "regulatory" results, are provided in a separate report. ${ }^{1}$ These cover the feed, concentrate, condensate and offgas streams for the Envelope $\mathrm{C}$ evaporation. The validation of regulatory data by SRTC is also provided separately. ${ }^{23}$ Described here are the preliminary results obtained by SRTC analysis of the process liquids and solids.

${ }^{23}$ Kubilius, W.P., Report of Analytical Data Validation of Regulatory Analyses for SRTC Contract WFO98-003: LC Evaporator Samples; Rev. 0, ESH-EMS-2001-0125, Westinghouse Savannah River Co., Aiken, SC, Jan. 13, 2001. 
WSRC-TR-2000-00469

SRT-RPP-2000-00043

Revision 1

\section{RESULTS AND DISCUSSION}

\section{Overview}

The initial boildown and steady-state portions of the evaporation experiment were completed during July 17-22, 2000. This included delays during the initial phase to replace pumps that had vacuum ratings slightly less than what was necessary. After sampling, shipping, and accounting for materials, the experimental apparatus was restarted and the final boildown was conducted. Samples were taken periodically and submitted later for analysis according to the Task Plan. ${ }^{19}$

\section{Initial Boildown}

The bench-scale evaporator was initially charged with feed and heated. Power to the heater rod was increased gradually to maintain a moderate temperature difference $\left(\sim 15^{\circ} \mathrm{C}\right)$ between the heater (i.e., inner surface of the heater rod) and the evaporator pot (i.e., bulk stirred liquid). As needed, the temperature of the condenser cooling water was adjusted to maintain the condenser vapor temperature at the design basis value of $40^{\circ} \mathrm{C}$. The profile for evaporator pot temperature (T2) and pressure for the initial boildown is shown in Figure 5.

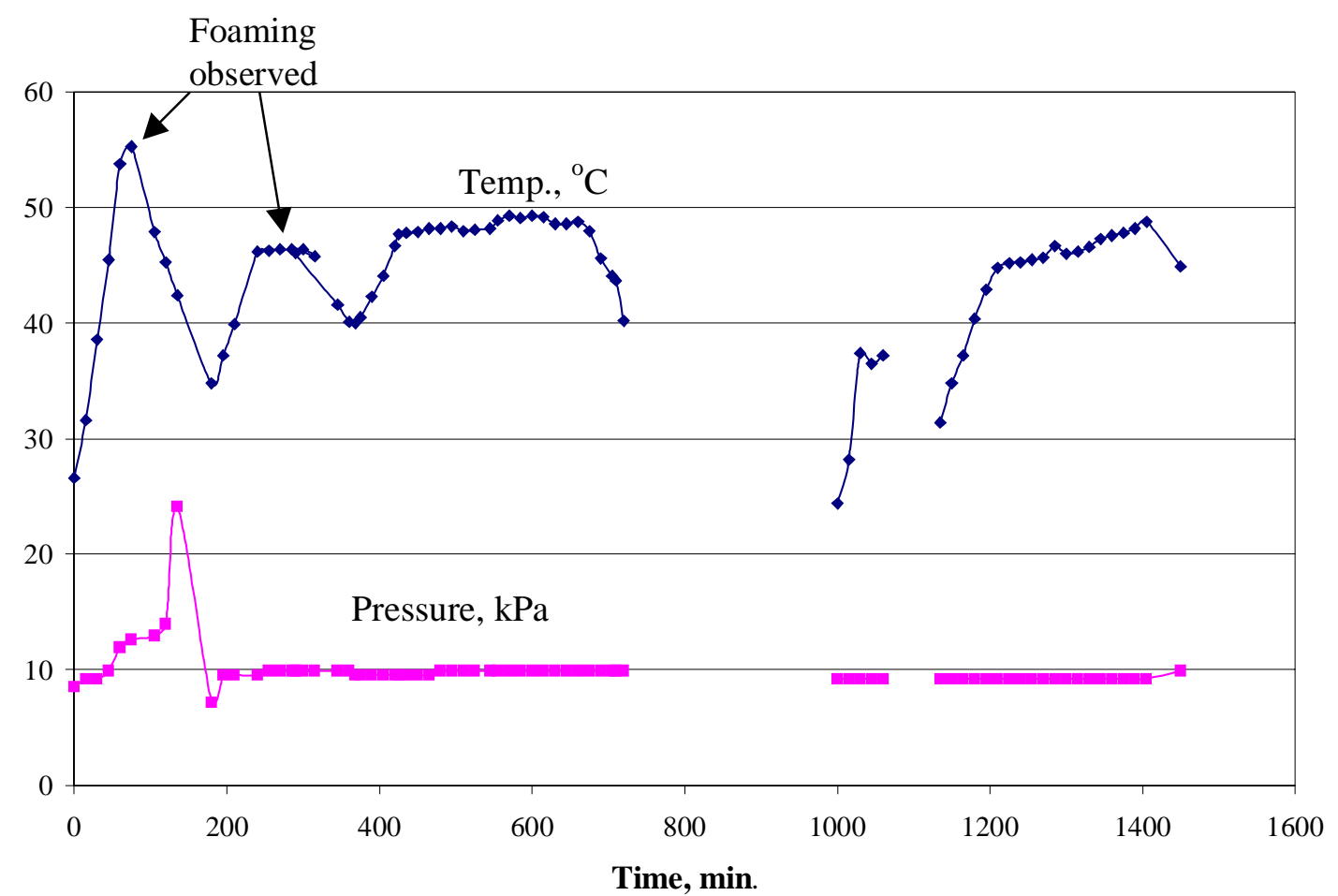

Figure 5. Operating conditions during initial boildown of Envelope $\mathrm{C}$. 
As indicated in Figure 5, foaming occurred during the first heat-up phase of the initial boildown (at $55^{\circ} \mathrm{C}$ ). Immediately, the heater was turned off. Since the foam was clearly capable of foaming up into the demister and evaporator overhead line, plans were made to add antifoam (at $1 \mathrm{~g} / \mathrm{L}$ concentrate), as specified in the Task Plan. ${ }^{19}$ During the next heat-up phase, boiling was first observed at $46^{\circ} \mathrm{C}$ (T2) which was slightly below the ESP model prediction of $50^{\circ} \mathrm{C}$. With the evaporator pot kept at $46^{\circ} \mathrm{C}$, foaming was observed again. A close-up photograph is shown in Figure 6. Dow Corning 1520-US antifoam was added (at $1 \mathrm{~g} / \mathrm{L}$ ) into the evaporator, and effectively eliminated the foam. For a visualization of the foaming, and the effectiveness of the antifoam, refer to the attached $\mathrm{CD}^{24}$, which contains a five-minute movie, viewable using Windows ${ }^{\mathrm{TM}}$ Media Player.

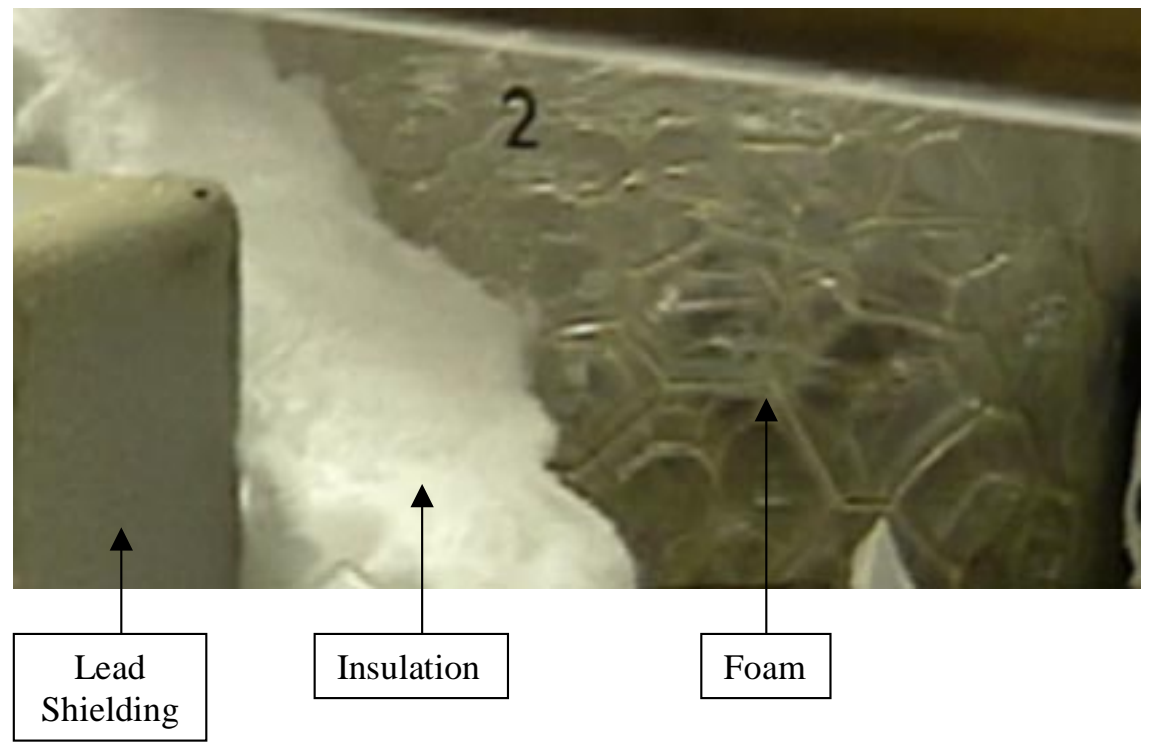

\section{Figure 6. Foaming observed during evaporation of Envelope C (AN102).}

Though Dow Corning 1520-US was effective at eliminating foam, new additions (at 1 $\mathrm{g} / \mathrm{L}$, or about $1.5 \mathrm{~g}$ per addition) were necessary every 2-3 hours, due in part to dilution effects from continuous pumping of feed and concentrate. In addition, the antifoam used is known to break down in high-pH solutions. ${ }^{25}$ The RPP customer chose to establish a baseline of comparison to the 242-A evaporator at Hanford, which also uses Dow Corning 1520-US. ${ }^{26}$ The measured vapor flux averaged $0.33 \mathrm{Kg} / \mathrm{min} / \mathrm{m}^{2}$, which is only $6 \%$ of the design basis vapor flux $\left(5.66 \mathrm{Kg} / \mathrm{min} / \mathrm{m}^{2}\right){ }^{27}$ This difference is due in part to

${ }^{24}$ Crowder,M.L., C.L. Crawford, H.H. Saito, and T.B.Calloway, Jr., "Foaming During Evaporation of Hanford Envelope C (Tank 241-AN-102)", J. Siler, prod., WSRC-VM-2001-00114 (SRT-RPP-200000058), Westinghouse Savannah River Company, Aiken, SC, May 31, 2001.

${ }^{25}$ Calloway, T.B., Verbal conversation with M. J. Hilger, Dow Corning Corp. Technical Services, concerning application of Dow 1520-US and other Dow antifoams to the RPP LAW Evaporators, Dec. 1, 2000.

${ }^{26}$ Hilger, M., personal communication with T.B. Calloway, November 2000.

${ }^{27}$ Washer, M., BNFL, Inc. Richland, WA, “Evaporator Info,” email to H. Saito, March 9, 2000. 
WSRC-TR-2000-00469

SRT-RPP-2000-00043

Revision 1

design differences between natural and forced circulation evaporators. The important point is that since foaming occurred at the low vapor flux in this study, it would also occur at the higher design basis flux.

Another important observation is that foaming occurred before the feed was concentrated. Initially the evaporator was charged with feed at $4.9 \mathrm{M} \mathrm{Na}$ up to the $1500 \mathrm{~mL}$ mark. However, the initial pot was slightly diluted by a $\sim 100 \mathrm{~mL}$ heel of $1.2 \mathrm{M} \mathrm{NaOH}$, which had been used for process blanks. The first observation of foaming (at $55^{\circ} \mathrm{C}$ ) occurred after only 20-40 mL of condensate had been produced. When the evaporator was heated a second time, and foaming was observed (at $44^{\circ} \mathrm{C}$ ), only $40-65 \mathrm{~mL}$ of condensate had been produced. Hence, the concentration was approximately $4.8 \mathrm{M}$ Na during initial foaming.

\section{Steady-state Evaporation}

Figure 7 shows the operating conditions during the steady-state portions of the experiment.

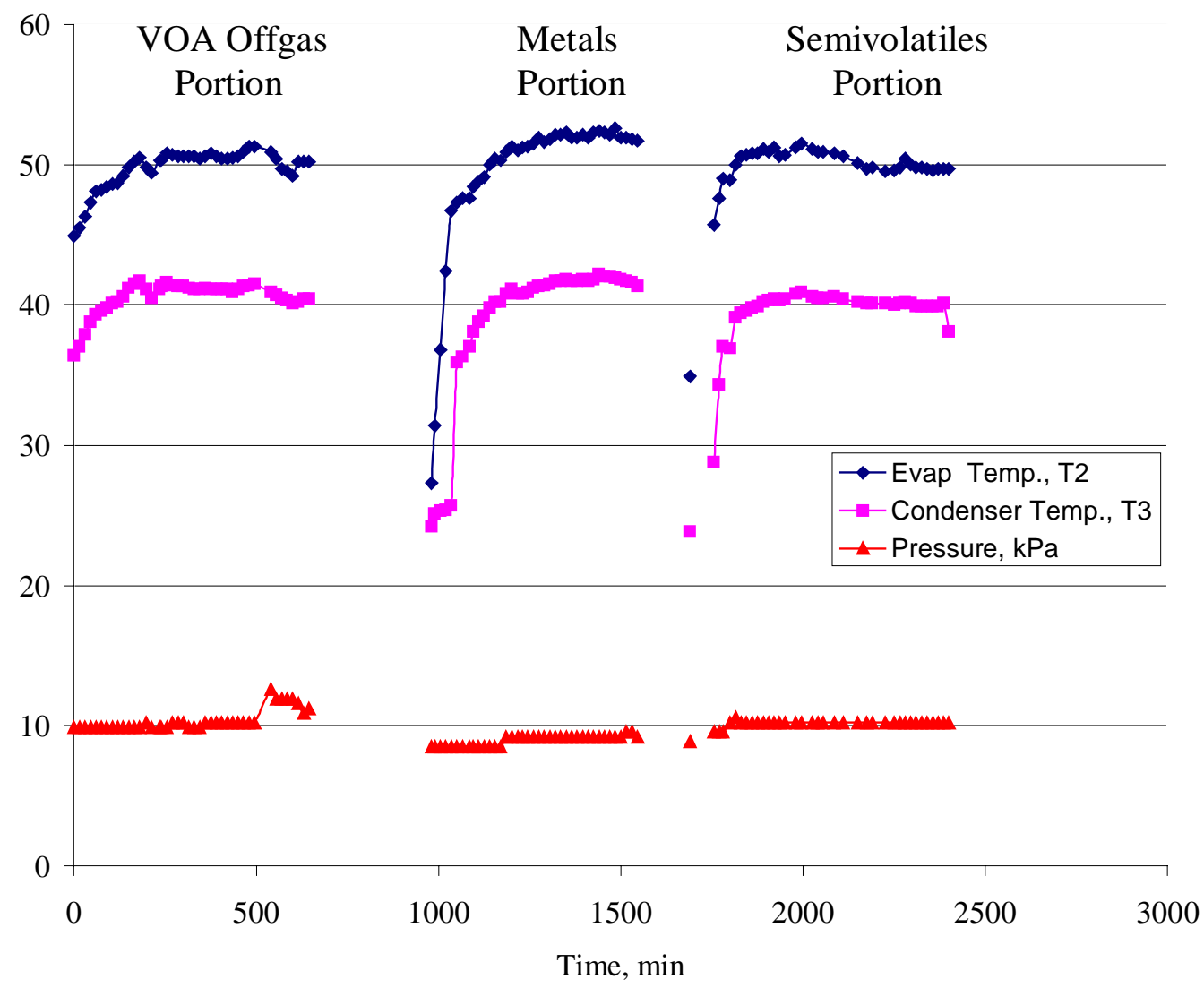

Figure 7. Steady-state operating conditions for Large $\mathbf{C}$ evaporation. 
WSRC-TR-2000-00469

SRT-RPP-2000-00043

Revision 1

When the concentrate in the evaporator reached an estimated value of 7.1 $\mathrm{M} \mathrm{Na}$, the initial boildown was complete and the first steady-state portion of the experiment began. Offgas sampling for volatiles was initiated and the feed and concentrate pumps were turned on. During the experiment a reasonable approximation of steady-state conditions ${ }^{18}$ was achieved. One main control, visual indication of level in the evaporator, was somewhat subjective due to a bubbling liquid surface. Also, the feed and concentrate pumps had to be adjusted periodically due to moderately decreased output over time. During steady-state operation, foaming occurred periodically and was eliminated with addition of antifoam (Dow 1520-US at $1 \mathrm{~g} / \mathrm{L}$ ) every 2-3 hours. A total of approximately $20 \mathrm{~g}$ of antifoam was added during the initial boildown and steady-state portions of the experiment. Scaling on the heater rod was not observed during steady-state operation.

Table 3 provides an overall material balance for the experiment. Feed processed and concentrate/condensate produced were measured with calibrated analytical balances. As shown in Table 3, the total mass fed to the evaporator was $16,640 \mathrm{~g}$, and the mass of products equaled $16,345 \mathrm{~g}$. This difference of $295 \mathrm{~g}$ (i.e., 1.8\%) most likely resulted from an accounting error related to the pump trap condensate. During the semivolatiles portion, the run sheet indicates that a volume of at least $500 \mathrm{~g}$ of condensate was observed in the pump traps. However, mass records indicate that only $250 \mathrm{~g}$ was collected. In this case, workers involved in sample recovery were different from those who made the experimental observations. The pump trap condensate was split for sampling purposes, and a labeling error may have occurred. If this was indeed the case, the total product mass was $16,595 \mathrm{~g}$, or about $0.3 \%$ less than the total mass fed. A difference of this size is not unreasonable.

Table 3. Overall Material Balance for Envelope C Evaporation

\begin{tabular}{|c|c|c|c|c|c|c|}
\hline & $\begin{array}{c}\text { Initial } \\
\text { Boildown } \\
\mathrm{g} \\
\end{array}$ & $\begin{array}{c}\text { Volatiles } \\
\text { portion } \\
\mathrm{g}\end{array}$ & $\begin{array}{c}\text { Metals } \\
\text { portion } \\
\mathrm{g}\end{array}$ & $\begin{array}{c}\text { Semivolatiles } \\
\text { Portion } \\
\mathrm{g} \\
\end{array}$ & $\begin{array}{c}\text { Post Run/ } \\
\text { Waste } \\
\text { g }\end{array}$ & $\begin{array}{l}\text { Total } \\
\mathrm{g}\end{array}$ \\
\hline Feed & 3000 & 5214 & 3726 & 4700 & & 16640 \\
\hline $\begin{array}{l}\text { Concentrate } \\
\text { Collected }\end{array}$ & 118 & 4064 & 2405 & 3433 & 210 & 10230 \\
\hline $\begin{array}{l}\text { Condensate } \\
\text { Collected }\end{array}$ & 159 & 1247 & 804 & 1251 & 200 & 3661 \\
\hline $\begin{array}{l}\text { Pump Trap } \\
\text { Condensate }\end{array}$ & 250 & 250 & 250 & $250^{\dagger}$ & & 1000 \\
\hline $\begin{array}{l}\text { Evaporator } \\
\text { Accumulation }\end{array}$ & \multicolumn{5}{|c|}{$\begin{array}{l}\text { Final mass }- \text { initial mass }(\text { heel })+\text { accumulation in tubing }= \\
(1150 \mathrm{~mL} * 1.32 \mathrm{~g} / \mathrm{mL})-100 \mathrm{~g}+26 \mathrm{~g}\end{array}$} & 1444 \\
\hline $\begin{array}{l}\text { Condenser } \\
\text { Accumulation }\end{array}$ & \multicolumn{5}{|c|}{$\begin{array}{l}\text { Final mass }- \text { initial mass }(\text { heel })= \\
(170 \mathrm{~mL}-160 \mathrm{~mL})^{*} 1 \mathrm{~g} / \mathrm{mL}\end{array}$} & 10 \\
\hline Total Product & & & & & & 16345 \\
\hline
\end{tabular}

$\dagger$ Potential recording error. Value may be $500 \mathrm{~g}$, as discussed above. 
WSRC-TR-2000-00469

SRT-RPP-2000-00043

Revision 1

The sodium concentration in the concentrate was analyzed several times, as shown in Table 4. Most analyses were by atomic absorption (AA), though one sample was also analyzed by inductively coupled plasma/emission spectrometry (ICPES). Though the analytical methods were internally consistent, there was a noticeable difference between them. The composite samples listed in Table 4 represent a mixture of concentrate from all steady-state portions of the experiment. However, more than half of the concentrate from the semivolatiles portion was shipped offsite for regulatory analysis. Thus, the composite had a smaller proportion of concentrate from that portion. The sodium analyses in Table 4 point to $7.1 \pm 0.7 \mathrm{M} \mathrm{Na}$ as the average concentrate concentration produced in this experiment. This matches the target concentration set forth before the experiment by the OLI ESP model to achieve $80 \%$ saturation.

Table 4. Sodium Concentration in Evaporator Products

\begin{tabular}{|c|c|c|c|c|c|c|}
\hline & \multicolumn{5}{|c|}{ Concentrate } & Condensate \\
\hline & $\begin{array}{c}\text { Semivol. } \\
\text { Portion }\end{array}$ & $\begin{array}{c}\text { Semivol. } \\
\text { Portion }\end{array}$ & $\begin{array}{c}\text { Vol. \& Metals } \\
\text { Portions }\end{array}$ & Composite & Composite & \\
\hline Method & AA & ICPES & AA & AA & ICPES & AA \\
\hline $\begin{array}{c}\text { Sodium } \\
\text { moles }\end{array}$ & 7.52 & 6.365 & 6.863 & 6.91 & 7.59 & 1.2 E-5 \\
\cline { 2 - 7 } liter & 7.24 & 6.288 & 6.769 & 6.80 & 7.67 & 7.0 E-7 \\
\cline { 2 - 7 } & 7.38 & & & 7.138 & & 2.3 E-6 \\
\cline { 2 - 7 } & 7.27 & & & 7.087 & & 2.3 E-6 \\
\hline Average & 7.35 & 6.33 & 6.82 & 6.98 & 7.63 & 4.3 E-6 \\
\hline
\end{tabular}

Analytical results for the feed, concentrate and condensate are shown in Table 5 and Table 6. Values for feed and concentrate represent averages of two samples each, tested in duplicate. The condensate values are averages for one sample tested in duplicate. More complete analytical results, including raw data, are included in Appendix B.

The decontamination factor, DF, is defined as the ratio of the concentration in the feed to that in the condensate. DF values are preceded by a "greater than" sign when the condensate result was "less than" the minimum detection limit. For major components in the feed, $\mathrm{Al}, \mathrm{Cr}, \mathrm{Na}, \mathrm{P}$, and $\mathrm{Sr}$, the DF across the evaporator was approximately $10^{4}-10^{5}$. An exception was $\mathrm{Ca}$, which behaved like minor elemental components $(<50 \mathrm{ppm})$ in exhibiting DF values on the order of $10^{2}-10^{3}$. A different group of minor components, the gamma-emitting isotopes, all had DF values greater than $10^{4}$. Taken together, DF values indicate that entrainment was effectively minimized by the demister in the overhead tube between the evaporator and the condenser.

The concentration factor, $\mathrm{CF}$, is the ratio of the concentration in the concentrate to that in the feed. Based on total volume, the expected $\mathrm{CF}$ is 1.53 . For this study, the average $\mathrm{CF}$ for most of the elements in Table 5 was 1.54. This average excludes silicon and tin, 
WSRC-TR-2000-00469

SRT-RPP-2000-00043

Revision 1

which appear to be outliers. The high CF for silicon is due to the periodic addition of a silicon-based antifoam agent throughout the experiment. Interestingly, the $\mathrm{CF}$ for sodium measured by ICPES, 1.44, is the lowest of the elements. However, the individual data points are reported with an error range of $\pm 10 \%$. Thus, a range of $\mathrm{CF}$ values is expected. Interestingly, the average $\mathrm{CF}$ for components above $100 \mathrm{ppm}$ was 1.50 . If the actual CF for sodium was 1.50 , the evaporator operated at a sodium concentration of 7.28 $\mathrm{M}$, which is similar to the sodium analysis results via atomic absorption (AA) in the range of 6.8 to $7.3 \mathrm{M}$, as shown in Table 4 .

Table 5. AN102 Evaporation - Elemental and Isotopic Analyses with Concentration and Decontamination Factors (CF and DF)

\begin{tabular}{|c|c|c|c|c|c|}
\hline & $\begin{array}{c}\text { Feed } \\
(\mathrm{mg} / \mathrm{L})\end{array}$ & $\begin{array}{c}\text { Concentrate } \\
(\mathrm{mg} / \mathrm{L})\end{array}$ & $\mathrm{CF}$ & $\begin{array}{c}\text { Condensate } \\
(\mathrm{mg} / \mathrm{L})\end{array}$ & $\mathrm{DF}$ \\
\hline \multicolumn{6}{|c|}{ ICP-Emission Spectrometry } \\
\hline Aluminum & 5361 & 7955 & 1.48 & 0.074 & $7.2 \mathrm{E}+04$ \\
\hline Boron & 13.4 & 21.4 & 1.60 & 0.029 & $4.7 \mathrm{E}+02$ \\
\hline Cadmium & 19.9 & 31.6 & 1.59 & $<0.003$ & $>6.6 \mathrm{E}+03$ \\
\hline Calcium & 111 & 169 & 1.52 & 0.157 & $7.1 \mathrm{E}+02$ \\
\hline Chromium & 70.3 & 111 & 1.58 & 0.007 & $1.0 \mathrm{E}+04$ \\
\hline Copper & 3.6 & 5.4 & 1.51 & 0.007 & $5.1 \mathrm{E}+02$ \\
\hline Lead & 44.4 & 74.0 & 1.67 & 0.037 & $1.2 \mathrm{E}+03$ \\
\hline Molybdenum & 21.5 & 33.3 & 1.55 & $<0.006$ & $>3.6 \mathrm{E}+03$ \\
\hline Nickel & 124 & 191 & 1.54 & 0.014 & $9.2 \mathrm{E}+03$ \\
\hline Phosphorus & 687 & 1027 & 1.50 & 0.038 & $1.8 \mathrm{E}+04$ \\
\hline Silicon & 33.9 & 82.7 & 2.44 & 0.286 & $1.2 \mathrm{E}+02$ \\
\hline Sodium & 111500 & 160400 & 1.44 & 0.231 & $4.8 \mathrm{E}+05$ \\
\hline Sodium (M) & 4.85 & 6.98 & & & \\
\hline Strontium & 126 & 193 & 1.53 & $<0.001$ & $>1.3 \mathrm{E}+05$ \\
\hline Tin & 11.0 & 19.7 & 1.80 & 0.020 & $5.5 \mathrm{E}+02$ \\
\hline \multicolumn{6}{|c|}{ Atomic Absorption } \\
\hline Sodium & NM & 160544 & NM & 0.283 & NA \\
\hline Potassium & 951 & 1196 & 1.26 & 0.014 & $6.8 \mathrm{E}+04$ \\
\hline \multicolumn{6}{|c|}{ Gamma Pulse Height Analysis } \\
\hline & $\mu \mathrm{Ci} / \mathrm{mL}$ & $\mu \mathrm{Ci} / \mathrm{mL}$ & & $\mu \mathrm{Ci} / \mathrm{mL}$ & \\
\hline Co-60 & 0.0399 & 0.0475 & 1.19 & $<3.62 \mathrm{E}-07$ & $>1.1 \mathrm{E}+05$ \\
\hline Cs-137 & 0.0528 & 0.0679 & 1.29 & $<1.20 \mathrm{E}-06$ & $>4.4 \mathrm{E}+04$ \\
\hline Eu-154 & 0.0342 & 0.0410 & 1.20 & $<1.25 \mathrm{E}-06$ & $>2.7 \mathrm{E}+04$ \\
\hline Eu-155 & 0.0232 & 0.0292 & 1.26 & $<1.82 \mathrm{E}-06$ & $>1.3 \mathrm{E}+04$ \\
\hline Am-241 & $<0.0163$ & 0.0236 & $>1.45$ & $<3.47 \mathrm{E}-06$ & NA \\
\hline Sr-90 & 1.35 & 1.40 & 1.04 & $\mathrm{NM}$ & NA \\
\hline
\end{tabular}

Note: For ICPES, analytes < 2 ppm in feed are not included.

$\mathrm{NA} / \mathrm{NM}=$ Not available/Not measured 
WSRC-TR-2000-00469

SRT-RPP-2000-00043

Revision 1

In Table 6, oxalate and phosphate ions both have CF values less than one. This is likely due to partial precipitation. The CF values for Total Inorganic and Organic Carbon (TIC/TOC) were 1.88 and 1.89, indicating an increase in carbon beyond what is expected from the evaporation process alone. The increased organic carbon is likely due to the addition of antifoam during the experiment, which was made of polydimethylsiloxane. The elevated inorganic carbon levels may be due to uptake of $\mathrm{CO}_{2}$ from the atmosphere by the solution, a characteristic of solutions with high $\mathrm{pH}$. Though the feed container was kept closed throughout storage and processing, some exposure to air inevitably occurred. The samples for feed analysis were taken a few months before the evaporation experiment was conducted. Hence, even a slow rate of $\mathrm{CO}_{2}$ uptake would effect the total carbon loading of the evaporator product.

Table 6. AN102 Evaporation - Analysis of Feed, Concentrate and Condensate

\begin{tabular}{|c|c|c|c|c|}
\hline & $\begin{array}{l}\text { Feed } \\
\mathrm{mg} / \mathrm{L}\end{array}$ & $\begin{array}{c}\text { Concentrate } \\
\mathrm{mg} / \mathrm{L}\end{array}$ & $\mathrm{CF}$ & $\begin{array}{c}\text { Condensate } \\
\mathrm{mg} / \mathrm{L}\end{array}$ \\
\hline \multicolumn{5}{|c|}{ Ion Chromatography - Anions } \\
\hline Chloride & 1575 & 1861 & 1.18 & $<20$ \\
\hline Fluoride & 766 & 976 & 1.27 & $<20$ \\
\hline Formate & 4567 & 5914 & 1.30 & $<100$ \\
\hline Nitrate & 85940 & 111800 & 1.30 & $<100$ \\
\hline Nitrite & 36220 & 44680 & 1.23 & $<100$ \\
\hline Oxalate & 1067 & 954 & 0.89 & $<100$ \\
\hline Sulfate & 5475 & 7026 & 1.28 & $<50$ \\
\hline Phosphate & 2196 & 2015 & 0.92 & $<100$ \\
\hline Free $\mathrm{OH}^{-}(\mathrm{M})$ & 1.24 & 1.46 & 1.18 & NM \\
\hline $\mathrm{AlO}_{2}^{-}(\mathrm{M})$ & NM & 0.26 & NA & NM \\
\hline Carbonate $(\mathrm{M})$ & NM & 0.31 & NA & NM \\
\hline \multicolumn{5}{|l|}{ General Properties } \\
\hline sp. G. $(\mathrm{g} / \mathrm{mL})$ & 1.23 & 1.31 & NA & NM \\
\hline $\begin{array}{l}\text { insoluble solids } \\
\text { (wt.\%, washed) }\end{array}$ & $<0.002$ & 0.02 & NA & NM \\
\hline $\begin{array}{l}\text { insoluble solids } \\
\text { (wt.\%, unwashed) }\end{array}$ & NM & 0.29 & NA & NM \\
\hline $\begin{array}{l}\text { soluble solids } \\
\text { (wt.\%) }\end{array}$ & 31.5 & 41.18 & 1.31 & NM \\
\hline \multicolumn{5}{|c|}{ Total Inorganic Carbon/Total Organic Carbon (TIC/TOC) } \\
\hline & $\mathrm{mg} / \mathrm{L}$ & $\mathrm{mg} / \mathrm{L}$ & $\mathrm{CF}$ & \\
\hline TIC & 5840 & 11000 & 1.88 & NM \\
\hline TOC & 11400 & 21500 & 1.89 & NM \\
\hline
\end{tabular}


WSRC-TR-2000-00469

SRT-RPP-2000-00043

Revision 1

Table 6 shows a concentrate density (specific gravity) of $1.31 \mathrm{~g} / \mathrm{mL}$. This value, measured with a volumetric flask, is about $4 \%$ lower than values obtained for other concentrate samples using a calibrated pipette (see Table B-4, Appendix B). The pipette results indicate a density of 1.33 at the end of initial boildown, and a density of 1.36 at the end of the first steady-state portion of the experiment. Assuming all sodium remains in the concentrate, density values can be used to predict sodium concentration. Based on feed values of $4.9 \mathrm{M} \mathrm{Na}$ and $1.23 \mathrm{~g} / \mathrm{mL}$, the densities of $1.31,1.33$, and $1.36 \mathrm{~g} / \mathrm{mL}$ correspond to sodium concentrations of $6.6,7.1$, and 7.6 M. The density values are within $4 \%$, which is due in part to measurement error. However, the variations in density also indicate that fluctuations in concentration occurred during the experiment.

Organic Analyses

Five concentrate samples were submitted for volatile and semivolatile organic compound (VOC and SVOC) analysis at SRTC. Details of the analyses can be found in Appendix C. The Sample ID indicates which steady-state portion $(\mathrm{VOA}=$ part $1, \mathrm{M} 60=$ part 2) of the experiment the samples derived from.

Only tetrahydrofuran (THF) in quantities delineated below was determined to be present in VOC analysis. The limit of detection is $2.5 \mu \mathrm{g} / \mathrm{L}$. Other VOC's, listed in Appendix C, were not detected, and had detection limits ranging from 1 to $5 \mu \mathrm{g} / \mathrm{L}$.

Table 7. Volatile (VOC) Results for Envelope C Evaporation Products

\begin{tabular}{|l|c|c|}
\hline Sample Type & Run Portion & THF, $\mu \mathrm{g} / \mathrm{L}$ \\
\hline Concentrate & VOA & 260 \\
\cline { 2 - 3 } & M60 & $\mathrm{U}^{*}$ \\
\hline \multirow{2}{*}{ Condensate } & VOA & 280 \\
\cline { 2 - 3 } & M60 & 72 \\
\hline Blank & & 3.8 \\
\hline
\end{tabular}

$* \mathrm{U}-$ not detected

The vapor pressure of THF is about five times greater than that of water at the evaporator operating temperature, $50^{\circ} \mathrm{C} .{ }^{28}$ Thus, it is not surprising that THF was present in both condensate samples but in only one of the concentrate samples. A companion report ${ }^{1}$ details regulatory results for the feed and all product streams. In general, THF appears in product streams as offgas $>$ condensate $>$ concentrate, which is characteristic of volatile compounds.

The results of analysis of semivolatile organic compounds (SVOC) are presented in Table 8. Twelve SVOCs were detected in the concentrate, and two of these were also found in the condensate. Three of the SVOCs were alcohols that did not contain other functional groups. A diamine was detected, as was tributyl phosphate, a common extractant in

${ }^{28}$ Reid, R.C., J.M. Prausnitz, and B.E. Poling, The Properties of Gases and Liquids, $4^{\text {th }}$ ed., McGraw-Hill: New York, 1987. 
WSRC-TR-2000-00469

SRT-RPP-2000-00043

Revision 1

actinide operations. Four SVOCs could not be identified, and three could only be assigned to a general group.

Table 8. Semivolatile (SVOC) Results for Envelope C Evaporation Products

\begin{tabular}{|c|c|c|c|c|c|c|}
\hline Retention & & Cons & trate & Conc & isate & Blank \\
\hline $\begin{array}{c}\text { Time, } \\
\text { min }\end{array}$ & Analyte & $\begin{array}{c}\text { (VOA) } \\
\mathrm{mg} / \mathrm{L}\end{array}$ & $\begin{array}{l}(\mathrm{M} 60) \\
\mathrm{mg} / \mathrm{L}\end{array}$ & $\begin{array}{l}\text { (VOA) } \\
\mathrm{mg} / \mathrm{L}\end{array}$ & $\begin{array}{c}(\mathrm{M} 60) \\
\mathrm{mg} / \mathrm{L}\end{array}$ & $\mathrm{mg} / \mathrm{L}$ \\
\hline 7.95 & 4-methyl-3-hexanol & 25 & 33 & $\mathrm{U}$ & $\mathrm{U}$ & $\mathrm{U}$ \\
\hline 12.02 & 5-Butyl-5-nonanol & 12 & 11 & $\mathrm{U}$ & $\mathrm{U}$ & $\mathrm{U}$ \\
\hline $11.98 \pm .01$ & Unidentified & 9.0 & 14 & $\mathrm{U}$ & $\mathrm{U}$ & $\mathrm{U}$ \\
\hline 23.15 & $\begin{array}{l}\text { Unidentified } \\
\text { Nitrophthalate Ester }\end{array}$ & 8.1 & 12 & $\mathrm{U}$ & $\mathrm{U}$ & $\mathrm{U}$ \\
\hline 15.11 & $\begin{array}{l}\text { 4,5-Dichloro- } \\
\text { phenylenediamine }\end{array}$ & 6.9 & 7.2 & $\mathrm{U}$ & $\mathrm{U}$ & $\mathrm{U}$ \\
\hline $12.15 \pm .01$ & Unidentified & 5.5 & 6.0 & $\mathrm{U}$ & $\mathrm{U}$ & $\mathrm{U}$ \\
\hline 18.87 & Tributyl phosphate & 2.5 & 2.6 & 0.30 & 0.28 & 0.14 \\
\hline 18.47 & $\begin{array}{l}\text { Unidentified } \\
\text { Nitroaromatic }\end{array}$ & 2.2 & $\mathrm{U}$ & $\mathrm{U}$ & $\mathrm{U}$ & $\mathrm{U}$ \\
\hline 16.83 & $\begin{array}{l}\text { 2,7- } \\
\text { Naphthalenediol }\end{array}$ & 1.3 & 0.36 & 0.37 & 0.34 & $\mathrm{U}$ \\
\hline $22.75 \pm .01$ & $\begin{array}{l}\text { Unidentified } \\
\text { Nitrophthalate Ester }\end{array}$ & 1.0 & 1.8 & $\mathrm{U}$ & $\mathrm{U}$ & $\mathrm{U}$ \\
\hline 14.5 & Unidentified & 1.0 & $\mathrm{U}$ & $\mathrm{U}$ & $\mathrm{U}$ & $\mathrm{U}$ \\
\hline 30.49 & Unidentified & $\mathrm{U}$ & 1.0 & $\mathrm{U}$ & $\mathrm{U}$ & $\mathrm{U}$ \\
\hline
\end{tabular}

*U - not detected

Additionally, the SVOC study of this sample set included isotopic dilution analysis of tributyl phosphate (TBP) and N-nitrosodimethylamine (NDMA) using deuterium labelled isotopic diluents, TBP-d27 and NDMA-d6 respectively, as quantitation standards. Selected ion monitoring was used for mass spectral determination of the analytes and diluents. The results of this study are shown in Table 9. TBP quantitation values presented here are similar to, and much more reliable than the values given above because of the intrinsic accuracy of the method of quantitation employed.

Table 9. Organic Analyses Using Isotopic Dilution

\begin{tabular}{|l|c|c|c|c|}
\hline Sample Type & $\begin{array}{c}\text { Run } \\
\text { Portion }\end{array}$ & $\begin{array}{c}\text { MDL } \\
\mathrm{mg} / \mathrm{L}\end{array}$ & $\begin{array}{c}\text { TBP } \\
\mathrm{mg} / \mathrm{L}\end{array}$ & $\begin{array}{c}\text { NDMA } \\
\mathrm{mg} / \mathrm{L}\end{array}$ \\
\hline \multirow{2}{*}{ Concentrate } & VOA & 0.1 & 2.5 & $\mathrm{U}$ \\
\cline { 2 - 5 } & $\mathrm{M} 60$ & 0.1 & 2.0 & $\mathrm{U}$ \\
\hline \multirow{2}{*}{ Condensate } & VOA & 0.02 & 0.18 & 0.080 \\
\cline { 2 - 5 } & $\mathrm{M} 60$ & 0.02 & 0.22 & 0.24 \\
\hline Blank & & 0.01 & 0.11 & $\mathrm{U}$ \\
\hline
\end{tabular}

*U - not detected 
Organic analyses were also conducted on the antifoam agent, Dow 1520-US. No semivolatiles were found above the method detection limit of $0.025 \mathrm{mg} / \mathrm{L}$. A search for volatiles of interest detected some, which are included in Appendix C. It is important to note that trace components of the antifoam were not likely to appear in the liquid product streams, since the antifoam was diluted 1000-fold when added.

Organic analyses of the feed by SRTC were not part of this study. However, analyses according to SW-846 protocol were conducted on all feed and product streams. These regulatory results are reported separately. ${ }^{1}$

\section{Final Boildown}

After the steady-state experiment and regulatory sampling were complete, a final boildown of the Envelope $\mathrm{C}$ solution was conducted to determine the solubility endpoint. The evaporator, containing $1150 \mathrm{~mL}$ of concentrate, was filled to $1500 \mathrm{~mL}$ with feed. Once heat was applied, no more feed was added nor was concentrate removed. The operating conditions for the final boildown were the same as those for steady-state.

During the final boildown, the amount of solids in the solution increased with time. This was observed visually and confirmed analytically. A total of eight samples were taken during the final boildown. A photograph of the samples is provided in Figure 8. If viewed in color, Figure 8 shows that the last bottle is a lighter color due to its high concentration of solids, which are colorless or white.

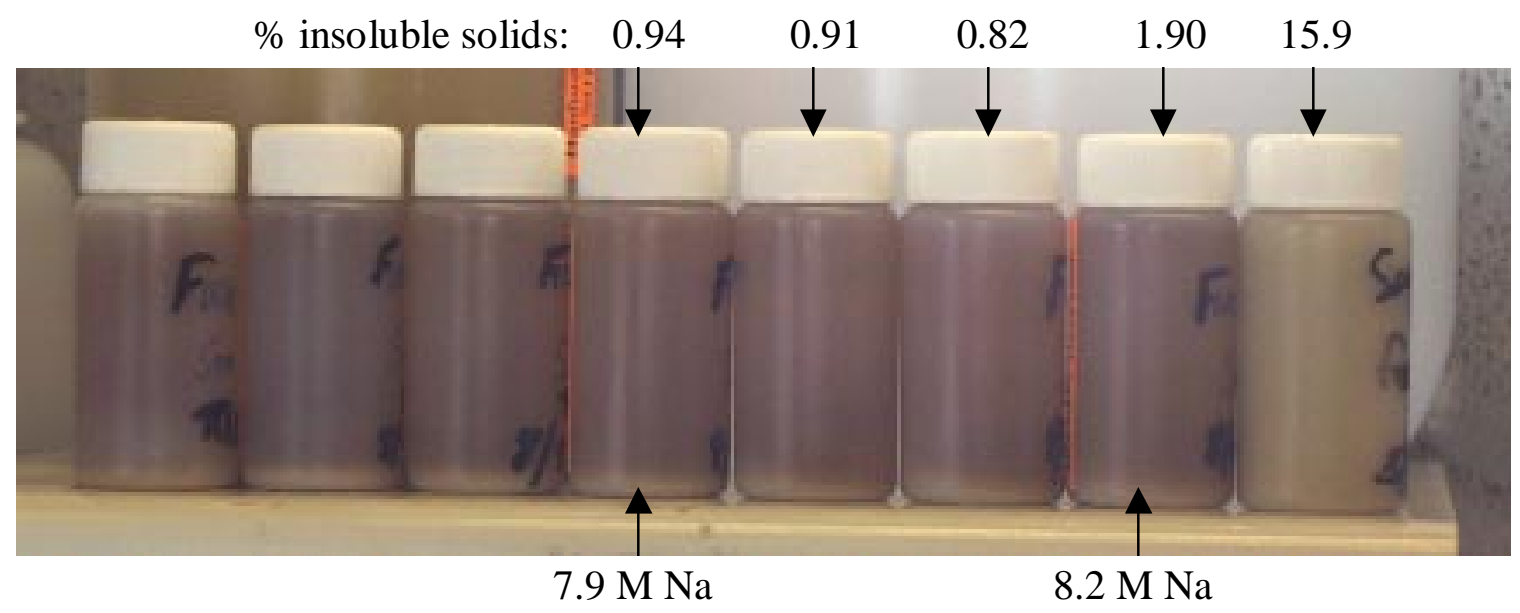

Figure 8. Samples 1-8 from final boildown (in numerical and chronological order, from left to right).

Final Boildown samples 4 - 8 were analyzed for density, \% insoluble solids, and solids characterization (XRD). Limited sodium measurements by AA were also made on the heterogeneous mixtures. The results are included in Table 10. 
WSRC-TR-2000-00469

SRT-RPP-2000-00043

Revision 1

Table 10. Analytical Results for Final Boildown Samples

\begin{tabular}{|c|c|c|c|c|c|}
\hline Sample & $\begin{array}{l}\text { Elapsed } \\
\text { Time } \\
\text { (min) }\end{array}$ & $\begin{array}{l}\text { Sodium } \\
\text { Conc. } \\
\text { (M) }\end{array}$ & $\begin{array}{l}\text { \% insoluble } \\
\text { solids } \\
\text { (unwashed) }\end{array}$ & $\begin{array}{l}\text { Density } \\
(\mathrm{mg} / \mathrm{L})\end{array}$ & $\begin{array}{l}\text { Solids identified } \\
\text { (XRD) }\end{array}$ \\
\hline 4 & 215 & 7.92 & 0.94 & 1.360 & $\mathrm{Na}_{2} \mathrm{C}_{2} \mathrm{O}_{4}$ \\
\hline 5 & 260 & & 0.91 & 1.368 & $\begin{array}{c}\mathrm{Na}_{2} \mathrm{C}_{2} \mathrm{O}_{4}, \mathrm{SiO} 2 \\
\mathrm{Na}_{7} \mathrm{~F}\left(\mathrm{PO}_{4}\right)_{3} \bullet 19 \mathrm{H}_{2} \mathrm{O}\end{array}$ \\
\hline 6 & 295 & & 0.82 & 1.375 & $\begin{array}{c}\mathrm{Na}_{2} \mathrm{C}_{2} \mathrm{O}_{4}, \mathrm{NaNO}_{3} \\
\mathrm{Na}_{3} \mathrm{H}\left(\mathrm{CO}_{3}\right) 2\left(\mathrm{H}_{2} \mathrm{O}\right)_{2}\end{array}$ \\
\hline 7 & 320 & 8.20 & 1.90 & 1.387 & $\begin{array}{c}\mathrm{Na}_{2} \mathrm{CO}_{3} \cdot \mathrm{H}_{2} \mathrm{O}, \mathrm{Na}_{2} \mathrm{C}_{2} \mathrm{O}_{4} \\
\mathrm{Na}_{3} \mathrm{H}\left(\mathrm{CO}_{3}\right) 2\left(\mathrm{H}_{2} \mathrm{O}\right)_{2} \\
\mathrm{Na}_{7} \mathrm{~F}\left(\mathrm{PO}_{4}\right)_{3} \cdot 19 \mathrm{H}_{2} \mathrm{O}\end{array}$ \\
\hline 8 & 330 & & 15.9 & 1.473 & $\mathrm{Na}_{2} \mathrm{CO}_{3} \cdot \mathrm{H}_{2} \mathrm{O}, \mathrm{Na}_{2} \mathrm{C}_{2} \mathrm{O}_{4}$ \\
\hline
\end{tabular}

Comparison of the wt.\% insoluble solids from samples 4-7 of Table 8, in the range of 0.94 to $1.90 \mathrm{wt} . \%$ insoluble solids, to the starting concentrate value of $0.29 \mathrm{wt} . \%$ insoluble solids (Table 6) indicates that the amount of insoluble solids increased with final boildown concentration of the concentrate. The final sample of the final boildown demonstrated a dramatic solubility endpoint, in which measured insoluble solids increased eight-fold in a few minutes to $15.9 \mathrm{wt} . \%$. These solids were submitted for $\mathrm{x}$ ray diffraction (XRD), which showed sodium carbonate hydrate, $\mathrm{Na}_{2} \mathrm{CO}_{3} \cdot \mathrm{H}_{2} \mathrm{O}$, as the major precipitant at the endpoint. XRD also identified sodium oxalate, $\mathrm{Na}_{2} \mathrm{C}_{2} \mathrm{O}_{4}$, in all samples, as predicted by the OLI model. As before, XRD blanks were also tested using the filtered supernate. This demonstrated that solids, such as talc (i.e., $\operatorname{Mg}_{3} \operatorname{Si}_{4} \mathrm{O}_{10}(\mathrm{OH})_{2}$ ) were dissolved but remained on the filter paper after drying since some solution remained in the interstitial spaces of the filter paper.

Before the experiment, the OLI model predicted that a double salt, $\mathrm{Na} 7 \mathrm{~F}\left(\mathrm{PO}_{4}\right)_{3} \bullet 19 \mathrm{H} 2 \mathrm{O}$, would be the major precipitating species at $8.5 \mathrm{M} \mathrm{Na}$. This compound was identified as a minor component by XRD in samples 5 and 7. As noted before, the Envelope $\mathrm{C}$ solution, due to its high $\mathrm{pH}(\sim 14)$, probably absorbed $\mathrm{CO}_{2}$ from the atmosphere over time. This would have skewed the actual composition away from that used in the model predictions, and resulted in carbonate species precipitating first. Since the solubility endpoint occurred just a few minutes after sample 7 was obtained, the concentration at the endpoint was approximately $8.2 \mathrm{M} \mathrm{Na}$. Assuming all sodium remained in the concentrate, a mass balance shows that the density values 1.360 and $1.387 \mathrm{~g} / \mathrm{mL}$ correspond to 7.6 and 8.2 M Na, respectively.

After the final boildown, the concentrate from the various portions of the experiment (VOA, Method 0060, SVOA) was combined, along with the remaining feed. The final boildown concentrate that contained high solids was also recombined with the condensate, and this sample was also combined with the final concentrate composite. The result, approximately 7.5 liters of AN102 concentrate, was used as the feed material for the Envelope C melter vitrification study at SRTC. ${ }^{2}$ The melter feed is prototypic of what 
WSRC-TR-2000-00469

SRT-RPP-2000-00043

Revision 1

is expected in the RPP-WTP LAW melter. ${ }^{2}$ An exception is that the LAW melter offgas was not included in the feed material of this study. An earlier study showed that the LAW melter offgas stream contains insoluble salts and glass formers, ${ }^{3}$ which may affect evaporator performance. Therefore, future studies should include simulated or actual recycle streams to more fully understand the operation of the expected RPP-WTP LAW evaporator.

\section{CONCLUSIONS}

A bench-scale evaporator designed at SRTC was operated semi-continuously at $50^{\circ} \mathrm{C}$ and $9.5 \mathrm{kPa}$ to concentrate a 15-L pretreated sample of Envelope C (AN102) from 4.9 to 7.1 $\mathrm{M} \mathrm{Na}$. This study included three ten-hour operating segments to obtain offgas samples for (1) volatiles, (2) metals/radionuclides, and (3) semivolatiles, in that order. These offgas samples, as well as liquid samples of feed, concentrate, and condensate, were obtained per EPA SW-846 methods. Samples were analyzed by a laboratory that routinely performs analyses according to EPA SW-846 protocol. Those results will be published separately. ${ }^{1}$ Analytical results from SRTC analyses are included in this report.

The results of this investigation lead to the following conclusions.

1. Significant foaming occurred in the Melter Feed Evaporator for pretreated Envelope $\mathrm{C}$ (AN102).

2. Dow 1520-US antifoam eliminates foaming in pretreated Envelope $\mathrm{C}$ liquid, but additions of $1 \mathrm{~g} / \mathrm{L}$ were necessary every two to three hours. Loss of effectiveness is attributed to both dilution effects and likely chemical breakdown at high $\mathrm{pH}$.

3. Scaling was not observed on the heater during steady-state operation, which involved heat flux values of 6.0 to $6.3 \mathrm{~W} / \mathrm{cm}^{2}$.

4. The experimental evaporator effectively concentrated the feed solution, as gammaproducing radionuclides were all below detection limits (typically $1 \times 10^{-6} \mu \mathrm{Ci} / \mathrm{mL}$ ) in the condensate.

5. Consistent with OLI ESP model predictions, sodium oxalate solids (at $0.3 \mathrm{wt} \%$ insoluble solids) were present in the evaporator at steady-state conditions (7.1 M Na). During the final boildown, a dramatic solubility endpoint occurred at $\sim 8.2 \mathrm{M} \mathrm{Na}$. The dominant precipitating species was $\mathrm{NaCO}_{3} \cdot \mathrm{H}_{2} \mathrm{O}$, likely due to uptake of $\mathrm{CO}_{2}$ from the atmosphere to yield this compound. The OLI ESP model had predicted the double salt, $\mathrm{Na}_{7} \mathrm{~F}\left(\mathrm{PO}_{4}\right)_{3} \bullet 19 \mathrm{H}_{2} \mathrm{O}$ as the major precipitant, with saturation at $8.5 \mathrm{M} \mathrm{Na}$, but it was only found in small quantities. 
WSRC-TR-2000-00469

SRT-RPP-2000-00043

Revision 1

\section{ACKNOWLEDGMENTS}

The authors acknowledge the excellent contributions of the following personnel:

From SRTC: Daro Ferrara, lead for regulatory sampling and contracting; Nick Odom, equipment specialist; Sarah Brown, Mike Lee, Shirley McCollum, and Elaine Pearson, technicians; Gary Dobos and Curtis Sexton, Glass Shop; Alex Choi, lead for OLI ESP

modeling; Robert Ray, lead for packaging/shipment of regulatory samples; Ned Bibler, technical advisor; and Jeff Siler, producer of the attached video.

From Oak Ridge's Y-12 National Security Complex: Brad Stinnett and Eddie Warren, gas sampling technicians.

Each of these individuals made a vital contribution to the success of the project. 
WSRC-TR-2000-00469

SRT-RPP-2000-00043

Revision 1

\section{APPENDICES}

\section{Appendix A: Description of SW-846 Methods}

General Description of SW-846 Sampling Methods \& Deviations used to Evaluate the Offgas from the Evaporation of Envelope C (AN102) ${ }^{29}$

\section{Method 0031}

Method 0031, "Sampling Method for Volatile Organic Compounds (SMVOC)", is applicable to volatile organic compounds that have a boiling point between $-15^{\circ} \mathrm{C}$ and $121^{\circ} \mathrm{C}$. The method typically employs a sampling module and meter box using a glasslined probe heated to $130 \pm 5^{\circ} \mathrm{C}$. The gas stream is cooled to $20^{\circ} \mathrm{C}$ by passage through a water-cooled condenser and volatile organic compounds are collected on a set of three sorbent traps $\left(\right.$ Tenax $^{\circledR}-\mathrm{GC} /$ Tenax $^{\circledR}-\mathrm{GC} /$ Anasorb $\left.{ }^{\circledR}-747\right)$. The first and second traps contain $1.6 \mathrm{~g}$ of Tenax ${ }^{\circledR}-\mathrm{GC}$ each and the third trap (back trap) contains $5.0 \mathrm{~g}$ of Anasorb $^{\circledR}-747$. The sorbent tubes are glass tubes with approximate dimensions of $10 \mathrm{~cm}$ $x 1.6 \mathrm{~cm}$ ID. The sampling module contains a condensate trap after the two Tenax ${ }^{\circledR}-\mathrm{GC}$ tubes, a second condenser immediately upstream of the Anasorb ${ }^{\circledR}-747$ tube, and silica gel to remove any moisture before entering the meter box. Traps may be analyzed separately to assess breakthrough or combined to improve detection limits. Field application for volatile organic compounds with boiling points less than $0^{\circ} \mathrm{C}$ should be supported with laboratory data obtained to demonstrate the efficiency of the sampling and analysis method. Method 0031 is generally not applicable to polar water-soluble and reactive volatile organic compounds. The method is applicable to the determination of volatile organic compounds in the gaseous effluent of stationary sources with an upper concentration limit of 1.5 parts per million (ppm). The method is designed to be operated no slower than $0.25 \mathrm{~L} / \mathrm{min}$, and no faster than $1 \mathrm{~L} / \mathrm{min}$. At an operating rate of $1 \mathrm{~L} / \mathrm{min}$, the traps are replaced every $20 \mathrm{~min}$, and, at $0.5 \mathrm{~L} / \mathrm{min}$, the traps are replaced every $40 \mathrm{~min}$ in a typical measurement application on the effluent of a stationary source. In the application of Method 0031 in this regulatory study, the entire off-gas stream was directed through the sampling module from a vacuum pump that had condensate beakers to remove some of the liquid that could condense within the vacuum pump and harm it. The liquid condensed upstream of the sampling module was collected and analyzed. Based on the anticipated mass loading of volatile organics on the traps, it was judged that the total volume of gas sample could be extended beyond the $20 \mathrm{~L}$ of a typical effluent measurement.

\section{Method 0010}

Method 0010, "Modified Method 5 Sampling Train," is applicable to the determination of semivolatile Principal Organic Hazardous Organic Compounds (POHCs) from incineration systems. Gaseous and particulate pollutants are withdrawn from an emission source at an isokinetic sampling rate and collected in a multi-component sampling train

${ }^{29}$ Gibson, L.V., Jr., Email to M. Crowder on December 4, 2000. 
WSRC-TR-2000-00469

SRT-RPP-2000-00043

Revision 1

that includes a high-efficiency glass- or quartz-fiber filter and a packed bed of porous polymeric adsorbent resin. The filter is used to collect organic-laden particulate matter and the porous polymeric resin to absorb semivolatile organic species. Semivolatile species are defined as compounds with boiling points $>100^{\circ} \mathrm{C}$. The organic sampling module of the sampling train consists of three sections, including a gas conditioning section, a sorbent trap, and a condensate knockout trap. In a stationary source emissions measurement application, the sorbent trap is sized to contain approximately $20 \mathrm{~g}$ of porous polymeric resin (Rohm and Haas XAD-2 or equivalent) and is jacketed to maintain the internal gas temperature not to exceed $20^{\circ} \mathrm{C}$. The gas sampling rate is typically 0.5-1.0 dry standard cubic feet per minute (dscfm). In the application of Method 0010 in this regulatory study, the XAD-2 sorbent trap contained $4.6 \mathrm{~g}$ XAD-2 resin, since it was sized identical to the sorbent traps used to perform Method 0031. Also, a filter was omitted due to the expected absence of particulate matter. Again, the entire off-gas stream was directed through the sampling module, and the sampling duration was extended beyond that of a typical effluent measurement from a stationary emission source.

\section{Method 0060}

Method 0060, "Determination of Metals in Stack Emissions", is typically used to determine the concentrations of metals in stack emissions from hazardous waste incinerators and similar combustion processes. The stack sample is withdrawn isokinetically from the source. Particulate emissions are collected in a probe and on a heated filter and gaseous emissions are collected in a series of chilled impingers. The first liquid impingers contain an aqueous solution of dilute nitric acid combined with dilute hydrogen peroxide to remove most volatile metals. Two other impingers contain an acidic potassium permanganate solution to collect elemental mercury. Empty impingers may be placed for liquid knockout and to prevent accidental mixing of different chemicals in adjacent impingers. The last impinger contains a desiccant.

Method 0060 would be expected to collect radionuclides with chemical behavior similar to that of other metallic elements. The chemistry of most anions is such that collection is maximized in alkaline liquid media. Method 0050, "Isokinetic $\mathrm{HCl} / \mathrm{Cl}_{2}$ Emission Sampling Train", and Method 0051, "Midget Impinger $\mathrm{HCl} / \mathrm{Cl}_{2}$ Emission Sampling Train", are based on the collection of $\mathrm{HCl}$ gas in acidified water, which $\mathrm{Cl}_{2}$ gas has very low solubility and passes through to an alkaline absorbing solution. Method 0050 is distinguished by presence of a Teflon ${ }^{\circledR}$ mat or quartz-fiber filter to collect particulate matter containing chloride salts. Methods 0050 and 0051 have stated potential for collection of all halogens and halogen acids. For this particular regulatory study, separate measurement of anions and of metals and radionuclides was not possible due to the design of the experiment and available volume of feed sample. Due to a somewhat lower priority on determining the fate of anions, an approach was developed that sought to take advantage of the fact that anions would be soluble to some extent in the pump condensate liquids. Again, the entire off-gas stream was directed through the sampling module, and the sampling duration was extended beyond that of a typical effluent measurement from a stationary emission source. 
Appendix B: Analytical Results for Feed, Concentrate, and Condensate

Table B-1. Characterization of Envelope C (AN102) Evaporator: Feed

\begin{tabular}{|c|c|c|c|c|c|c|c|c|c|c|c|c|}
\hline Sample & & $\mathbf{1 A}$ & & 1B & & $2 \mathrm{~A}$ & & $2 B$ & & Average & St. Dev. & \% Rel.St.Dev. \\
\hline \multicolumn{13}{|l|}{ Radiochemical } \\
\hline & & $(\mu \mathrm{Ci} / \mathrm{mL})$ & & $(\mu \mathrm{Ci} / \mathrm{mL})$ & & $(\mu \mathrm{Ci} / \mathrm{mL})$ & & $(\mu \mathrm{Ci} / \mathrm{mL})$ & & $(\mu \mathrm{Ci} / \mathrm{mL})$ & $(\mu \mathrm{Ci} / \mathrm{mL})$ & \\
\hline Co-60 & & $3.81 \mathrm{E}-02$ & & $4.10 \mathrm{E}-02$ & & $4.15 \mathrm{E}-02$ & & $3.92 \mathrm{E}-02$ & & $3.99 \mathrm{E}-02$ & $1.56 \mathrm{E}-03$ & 3.9 \\
\hline Cs-137 & & $4.54 \mathrm{E}-02$ & & $4.66 \mathrm{E}-02$ & & $6.17 \mathrm{E}-02$ & & $5.75 \mathrm{E}-02$ & & $5.28 \mathrm{E}-02$ & $8.06 \mathrm{E}-03$ & 15.3 \\
\hline Eu-154 & & $2.93 \mathrm{E}-02$ & & $3.63 \mathrm{E}-02$ & & $3.71 \mathrm{E}-02$ & & $3.41 \mathrm{E}-02$ & & $3.42 \mathrm{E}-02$ & $3.49 \mathrm{E}-03$ & 10.2 \\
\hline Eu-155 & & $2.27 \mathrm{E}-02$ & & $2.38 \mathrm{E}-02$ & & $2.45 \mathrm{E}-02$ & & $2.18 \mathrm{E}-02$ & & $2.32 \mathrm{E}-02$ & $1.18 \mathrm{E}-03$ & 5.1 \\
\hline Am-241 & & $1.61 \mathrm{E}-02$ & $<$ & $1.38 \mathrm{E}-02$ & & $1.42 \mathrm{E}-02$ & & $2.10 \mathrm{E}-02$ & $<$ & $1.63 \mathrm{E}-02$ & $3.32 \mathrm{E}-03$ & 20.4 \\
\hline Total Alpha & & $8.95 \mathrm{E}-02$ & & $6.09 \mathrm{E}-02$ & & $7.59 \mathrm{E}-02$ & & $3.45 \mathrm{E}-02$ & & $6.52 \mathrm{E}-02$ & $2.36 \mathrm{E}-02$ & 36.1 \\
\hline Total Beta & & 4.38 & & 4.46 & & 4.11 & & 4.27 & & 4.31 & $1.52 \mathrm{E}-01$ & 3.5 \\
\hline Sr-90 & & 1.41 & & 1.21 & & 1.41 & & 1.37 & & 1.35 & $9.52 \mathrm{E}-02$ & 7.1 \\
\hline \multicolumn{13}{|c|}{ ICP-Mass Spectroscopy } \\
\hline & & $(\mathrm{mg} / \mathrm{L})$ & & $(\mathrm{mg} / \mathrm{L})$ & & $(\mathrm{mg} / \mathrm{L})$ & & $(\mathrm{mg} / \mathrm{L})$ & & $(\mathrm{mg} / \mathrm{L})$ & $(\mathrm{mg} / \mathrm{L})$ & \\
\hline mass 99 & & $2.77 \mathrm{E}+00$ & & $2.78 \mathrm{E}+00$ & & $2.78 \mathrm{E}+00$ & & $2.81 \mathrm{E}+00$ & & $2.78 \mathrm{E}+00$ & $1.98 \mathrm{E}-02$ & 0.7 \\
\hline Tc-99( $\mu \mathrm{Ci} / \mathrm{mL})$ & & 4.69E-02 & & $4.71 \mathrm{E}-02$ & & $4.71 \mathrm{E}-02$ & & $4.77 \mathrm{E}-02$ & & 4.72E-02 & $3.36 \mathrm{E}-04$ & 0.7 \\
\hline mass 230 & $<$ & $3.30 \mathrm{E}-03$ & $<$ & $3.30 \mathrm{E}-03$ & $<$ & $3.30 \mathrm{E}-03$ & $<$ & $3.30 \mathrm{E}-03$ & $<$ & $3.30 \mathrm{E}-03$ & $0.00 \mathrm{E}+00$ & 0.0 \\
\hline mass 231 & $<$ & $3.30 \mathrm{E}-03$ & $<$ & $3.30 \mathrm{E}-03$ & $<$ & $3.30 \mathrm{E}-03$ & $<$ & $3.30 \mathrm{E}-03$ & $<$ & $3.30 \mathrm{E}-03$ & $0.00 \mathrm{E}+00$ & 0.0 \\
\hline Mass $232(\mathrm{Th})$ & & $1.51 \mathrm{E}+00$ & & $1.46 \mathrm{E}+00$ & & $1.46 \mathrm{E}+00$ & & $1.45 \mathrm{E}+00$ & & $1.47 \mathrm{E}+00$ & $2.57 \mathrm{E}-02$ & 1.8 \\
\hline mass 233 & $<$ & $3.30 \mathrm{E}-03$ & $<$ & $3.30 \mathrm{E}-03$ & $<$ & $3.30 \mathrm{E}-03$ & $<$ & $3.30 \mathrm{E}-03$ & $<$ & $3.30 \mathrm{E}-03$ & $0.00 \mathrm{E}+00$ & 0.0 \\
\hline Mass $234(\mathrm{U})$ & $<$ & $3.30 \mathrm{E}-03$ & $<$ & $3.30 \mathrm{E}-03$ & $<$ & $3.30 \mathrm{E}-03$ & $<$ & $3.30 \mathrm{E}-03$ & $<$ & $3.30 \mathrm{E}-03$ & $0.00 \mathrm{E}+00$ & 0.0 \\
\hline Mass 235 (U) & & $8.88 \mathrm{E}-03$ & & $8.68 \mathrm{E}-03$ & & $1.07 \mathrm{E}-02$ & & $1.03 \mathrm{E}-02$ & & $9.63 \mathrm{E}-03$ & $9.96 \mathrm{E}-04$ & 10.3 \\
\hline Mass $236(\mathrm{U})$ & $<$ & $3.30 \mathrm{E}-03$ & $<$ & $3.30 \mathrm{E}-03$ & $<$ & $3.30 \mathrm{E}-03$ & $<$ & $3.30 \mathrm{E}-03$ & $<$ & $3.30 \mathrm{E}-03$ & $0.00 \mathrm{E}+00$ & 0.0 \\
\hline Mass $237(\mathrm{~Np})$ & & $8.78 \mathrm{E}-02$ & & 8.93E-02 & & 8.82E-02 & & 8.79E-02 & & $8.83 \mathrm{E}-02$ & $6.76 \mathrm{E}-04$ & 0.8 \\
\hline Mass $238(\mathrm{Pu} \& \mathrm{U})$ & & $8.64 \mathrm{E}-01$ & & $8.77 \mathrm{E}-01$ & & $9.39 \mathrm{E}-01$ & & $9.35 \mathrm{E}-01$ & & $9.03 \mathrm{E}-01$ & $3.89 \mathrm{E}-02$ & 4.3 \\
\hline Mass $239(\mathrm{Pu})$ & & $1.50 \mathrm{E}-02$ & & $1.54 \mathrm{E}-02$ & & $1.35 \mathrm{E}-02$ & & $1.41 \mathrm{E}-02$ & & $1.45 \mathrm{E}-02$ & $8.64 \mathrm{E}-04$ & 6.0 \\
\hline
\end{tabular}


WSRC-TR-2000-00469

\begin{tabular}{|c|c|c|c|c|c|c|c|c|c|c|c|c|}
\hline Mass $240(\mathrm{Pu})$ & $<$ & $3.30 \mathrm{E}-03$ & $<$ & $3.30 \mathrm{E}-03$ & $<$ & $3.30 \mathrm{E}-03$ & $<$ & $3.30 \mathrm{E}-03$ & $<$ & $3.30 \mathrm{E}-03$ & $0.00 \mathrm{E}+00$ & 0.0 \\
\hline Mass $241(\mathrm{Am} \mathrm{\&} \mathrm{Pu})$ & & $7.46 \mathrm{E}-03$ & & $7.83 \mathrm{E}-03$ & & 7.09E-03 & & 7.69E-03 & & $7.52 \mathrm{E}-03$ & $3.25 \mathrm{E}-04$ & 4.3 \\
\hline Mass $242(\mathrm{Pu})$ & $<$ & $3.30 \mathrm{E}-03$ & $<$ & $3.30 \mathrm{E}-03$ & $<$ & $3.30 \mathrm{E}-03$ & $<$ & $3.30 \mathrm{E}-03$ & $<$ & $3.30 \mathrm{E}-03$ & $0.00 \mathrm{E}+00$ & 0.0 \\
\hline Mass $243(\mathrm{Am})$ & $<$ & $3.30 \mathrm{E}-03$ & $<$ & $3.30 \mathrm{E}-03$ & $<$ & $3.30 \mathrm{E}-03$ & $<$ & $3.30 \mathrm{E}-03$ & $<$ & $3.30 \mathrm{E}-03$ & $0.00 \mathrm{E}+00$ & 0.0 \\
\hline Mass $244(\mathrm{Cm})$ & $<$ & $3.30 \mathrm{E}-03$ & $<$ & $3.30 \mathrm{E}-03$ & $<$ & $3.30 \mathrm{E}-03$ & $<$ & $3.30 \mathrm{E}-03$ & $<$ & $3.30 \mathrm{E}-03$ & $0.00 \mathrm{E}+00$ & 0.0 \\
\hline mass $245(\mathrm{Cm})$ & $<$ & $3.30 \mathrm{E}-03$ & $<$ & $3.30 \mathrm{E}-03$ & $<$ & $3.30 \mathrm{E}-03$ & $<$ & $3.30 \mathrm{E}-03$ & $<$ & $3.30 \mathrm{E}-03$ & $0.00 \mathrm{E}+00$ & 0.0 \\
\hline mass 246 & $<$ & $3.30 \mathrm{E}-03$ & $<$ & $3.30 \mathrm{E}-03$ & $<$ & $3.30 \mathrm{E}-03$ & $<$ & $3.30 \mathrm{E}-03$ & $<$ & $3.30 \mathrm{E}-03$ & $0.00 \mathrm{E}+00$ & 0.0 \\
\hline \multicolumn{13}{|c|}{ ICP-Emission Spectroscopy } \\
\hline & & $(\mathrm{mg} / \mathrm{L})$ & & $(\mathrm{mg} / \mathrm{L})$ & & $(\mathrm{mg} / \mathrm{L})$ & & $(\mathrm{mg} / \mathrm{L})$ & & $(\mathrm{mg} / \mathrm{L})$ & $(\mathrm{mg} / \mathrm{L})$ & \\
\hline $\mathrm{Ag}$ & & NA & & NA & & NA & & NA & & & & \\
\hline $\mathrm{Al}$ & & $5.39 \mathrm{E}+03$ & & $4.51 \mathrm{E}+03$ & & $5.70 \mathrm{E}+03$ & & $5.84 \mathrm{E}+03$ & & $5.36 \mathrm{E}+03$ & $6.01 \mathrm{E}+02$ & 11.2 \\
\hline B & & $1.37 \mathrm{E}+01$ & & $1.14 \mathrm{E}+01$ & & $1.39 \mathrm{E}+01$ & & $1.44 \mathrm{E}+01$ & & $1.34 \mathrm{E}+01$ & $1.32 \mathrm{E}+00$ & 9.9 \\
\hline $\mathrm{Ba}$ & $<$ & $1.82 \mathrm{E}-01$ & & 4.69E-01 & $<$ & $1.82 \mathrm{E}-01$ & $<$ & $1.82 \mathrm{E}-01$ & $<$ & $2.54 \mathrm{E}-01$ & $1.44 \mathrm{E}-01$ & 56.6 \\
\hline $\mathrm{Ca}$ & & $1.12 \mathrm{E}+02$ & & $9.40 \mathrm{E}+01$ & & $1.18 \mathrm{E}+02$ & & $1.20 \mathrm{E}+02$ & & $1.11 \mathrm{E}+02$ & $1.19 \mathrm{E}+01$ & 10.8 \\
\hline $\mathrm{Cd}$ & & $1.99 \mathrm{E}+01$ & & $1.67 \mathrm{E}+01$ & & $2.12 \mathrm{E}+01$ & & $2.19 \mathrm{E}+01$ & & $1.99 \mathrm{E}+01$ & $2.30 \mathrm{E}+00$ & 11.6 \\
\hline Co & & $1.57 \mathrm{E}+00$ & & $1.95 \mathrm{E}+00$ & & $1.46 \mathrm{E}+00$ & & $1.24 \mathrm{E}+00$ & & $1.56 \mathrm{E}+00$ & $2.96 \mathrm{E}-01$ & 19.0 \\
\hline $\mathrm{Cr}$ & & $7.07 \mathrm{E}+01$ & & $5.93 \mathrm{E}+01$ & & $7.46 \mathrm{E}+01$ & & $7.64 \mathrm{E}+01$ & & $7.03 \mathrm{E}+01$ & $7.67 \mathrm{E}+00$ & 10.9 \\
\hline $\mathrm{Cu}$ & & $3.58 \mathrm{E}+00$ & & $3.39 \mathrm{E}+00$ & & $3.61 \mathrm{E}+00$ & & $3.76 \mathrm{E}+00$ & & $3.58 \mathrm{E}+00$ & $1.53 \mathrm{E}-01$ & 4.3 \\
\hline $\mathrm{Fe}$ & & $2.14 \mathrm{E}+00$ & & $2.15 \mathrm{E}+00$ & & $1.70 \mathrm{E}+00$ & & $1.73 \mathrm{E}+00$ & & $1.93 \mathrm{E}+00$ & $2.47 \mathrm{E}-01$ & 12.8 \\
\hline $\mathrm{La}$ & & $1.25 \mathrm{E}+00$ & & $2.16 \mathrm{E}+00$ & $<$ & $1.00 \mathrm{E}+00$ & $<$ & $1.00 \mathrm{E}+00$ & $<$ & $1.35 \mathrm{E}+00$ & $5.49 \mathrm{E}-01$ & 40.6 \\
\hline $\mathrm{Li}$ & & $1.83 \mathrm{E}-01$ & & $5.34 \mathrm{E}-01$ & $<$ & $1.82 \mathrm{E}-01$ & $<$ & $1.82 \mathrm{E}-01$ & $<$ & $2.70 \mathrm{E}-01$ & $1.76 \mathrm{E}-01$ & 65.1 \\
\hline $\mathrm{Mg}$ & $<$ & $9.10 \mathrm{E}-02$ & & $9.70 \mathrm{E}-02$ & $<$ & $9.10 \mathrm{E}-02$ & $<$ & $9.10 \mathrm{E}-02$ & $<$ & $9.25 \mathrm{E}-02$ & $3.00 \mathrm{E}-03$ & 3.2 \\
\hline $\mathrm{Mn}$ & & $8.16 \mathrm{E}-01$ & & $7.83 \mathrm{E}-01$ & & 7.91E-01 & & $8.00 \mathrm{E}-01$ & & 7.98E-01 & $1.42 \mathrm{E}-02$ & 1.8 \\
\hline Mo & & $2.25 \mathrm{E}+01$ & & $1.81 \mathrm{E}+01$ & & $2.21 \mathrm{E}+01$ & & $2.32 \mathrm{E}+01$ & & $2.15 \mathrm{E}+01$ & $2.28 \mathrm{E}+00$ & 10.6 \\
\hline $\mathrm{Na}$ & & $1.10 \mathrm{E}+05$ & & $1.07 \mathrm{E}+05$ & & $1.16 \mathrm{E}+05$ & & $1.13 \mathrm{E}+05$ & & $1.12 \mathrm{E}+05$ & $3.54 \mathrm{E}+03$ & 3.2 \\
\hline $\mathrm{Ni}$ & & $1.23 \mathrm{E}+02$ & & $1.03 \mathrm{E}+02$ & & $1.33 \mathrm{E}+02$ & & $1.36 \mathrm{E}+02$ & & $1.24 \mathrm{E}+02$ & $1.53 \mathrm{E}+01$ & 12.3 \\
\hline $\mathrm{P}$ & & $7.05 \mathrm{E}+02$ & & $5.71 \mathrm{E}+02$ & & $7.30 \mathrm{E}+02$ & & $7.42 \mathrm{E}+02$ & & $6.87 \mathrm{E}+02$ & $7.88 \mathrm{E}+01$ & 11.5 \\
\hline $\mathrm{Pb}$ & & $4.40 \mathrm{E}+01$ & & $3.92 \mathrm{E}+01$ & & $4.73 \mathrm{E}+01$ & & $4.71 \mathrm{E}+01$ & & $4.44 \mathrm{E}+01$ & $3.75 \mathrm{E}+00$ & 8.4 \\
\hline $\mathrm{Si}$ & & $4.35 \mathrm{E}+01$ & & $1.21 \mathrm{E}+01$ & & $3.91 \mathrm{E}+01$ & & $4.09 \mathrm{E}+01$ & & $3.39 \mathrm{E}+01$ & $1.46 \mathrm{E}+01$ & 43.1 \\
\hline
\end{tabular}




\begin{tabular}{|c|c|c|c|c|c|c|c|c|c|c|c|c|}
\hline $\mathrm{Sn}$ & & $1.19 \mathrm{E}+01$ & & $9.82 \mathrm{E}+00$ & & $1.10 \mathrm{E}+01$ & & $1.12 \mathrm{E}+01$ & & $1.10 \mathrm{E}+01$ & 8.72E-01 & 7.9 \\
\hline $\mathrm{Sr}$ & & $1.27 \mathrm{E}+02$ & & $1.02 \mathrm{E}+02$ & & $1.37 \mathrm{E}+02$ & & $1.40 \mathrm{E}+02$ & & $1.26 \mathrm{E}+02$ & $1.70 \mathrm{E}+01$ & 13.5 \\
\hline Tc & & $2.83 \mathrm{E}+00$ & & $2.79 \mathrm{E}+00$ & & $2.41 \mathrm{E}+00$ & & $2.05 \mathrm{E}+00$ & & $2.52 \mathrm{E}+00$ & $3.64 \mathrm{E}-01$ & 14.4 \\
\hline $\mathrm{Ti}$ & & $3.05 \mathrm{E}-01$ & & 7.63E-01 & $<$ & $1.82 \mathrm{E}-01$ & $<$ & $1.82 \mathrm{E}-01$ & $<$ & $3.58 \mathrm{E}-01$ & $2.76 \mathrm{E}-01$ & 77.1 \\
\hline $\mathrm{V}$ & & $6.07 \mathrm{E}-01$ & & $1.29 \mathrm{E}+00$ & $<$ & $2.73 \mathrm{E}-01$ & $<$ & $2.73 \mathrm{E}-01$ & $<$ & $6.10 \mathrm{E}-01$ & $4.78 \mathrm{E}-01$ & 78.4 \\
\hline $\mathrm{Zn}$ & & $1.40 \mathrm{E}+00$ & & $1.25 \mathrm{E}+00$ & & $1.30 \mathrm{E}+00$ & & $1.22 \mathrm{E}+00$ & & $1.29 \mathrm{E}+00$ & 7.83E-02 & 6.1 \\
\hline $\mathrm{Zr}$ & $<$ & $3.64 \mathrm{E}-01$ & $<$ & $3.64 \mathrm{E}-01$ & & $5.05 \mathrm{E}-01$ & $<$ & $3.64 \mathrm{E}-01$ & $<$ & $3.99 \mathrm{E}-01$ & 7.05E-02 & 17.7 \\
\hline \multicolumn{13}{|l|}{ IC Anions } \\
\hline & & $(\mathrm{mg} / \mathrm{L})$ & & $(\mathrm{mg} / \mathrm{L})$ & & $(\mathrm{mg} / \mathrm{L})$ & & $(\mathrm{mg} / \mathrm{L})$ & & $(\mathrm{mg} / \mathrm{L})$ & $(\mathrm{mg} / \mathrm{L})$ & \\
\hline Chloride & & $1.60 \mathrm{E}+03$ & & $1.56 \mathrm{E}+03$ & & $1.56 \mathrm{E}+03$ & & $1.59 \mathrm{E}+03$ & & $1.57 \mathrm{E}+03$ & $1.83 \mathrm{E}+01$ & 1.2 \\
\hline Fluoride & & $7.69 \mathrm{E}+02$ & & $7.71 \mathrm{E}+02$ & & $7.77 \mathrm{E}+02$ & & $7.46 \mathrm{E}+02$ & & $7.66 \mathrm{E}+02$ & $1.36 \mathrm{E}+01$ & 1.8 \\
\hline Formate & & $4.58 \mathrm{E}+03$ & & $4.65 \mathrm{E}+03$ & & $4.60 \mathrm{E}+03$ & & $4.45 \mathrm{E}+03$ & & $4.57 \mathrm{E}+03$ & $8.46 \mathrm{E}+01$ & 1.9 \\
\hline Nitrite & & $3.65 \mathrm{E}+04$ & & $3.66 \mathrm{E}+04$ & & $3.62 \mathrm{E}+04$ & & $3.56 \mathrm{E}+04$ & & $3.62 \mathrm{E}+04$ & $4.72 \mathrm{E}+02$ & 1.3 \\
\hline Nitrate & & $8.56 \mathrm{E}+04$ & & $8.69 \mathrm{E}+04$ & & $8.65 \mathrm{E}+04$ & & $8.48 \mathrm{E}+04$ & & $8.59 \mathrm{E}+04$ & $9.53 \mathrm{E}+02$ & 1.1 \\
\hline Sulfate & & $5.59 \mathrm{E}+03$ & & $5.51 \mathrm{E}+03$ & & $5.48 \mathrm{E}+03$ & & $5.32 \mathrm{E}+03$ & & $5.47 \mathrm{E}+03$ & $1.12 \mathrm{E}+02$ & 2.1 \\
\hline Phosphate & & $2.68 \mathrm{E}+03$ & & $1.73 \mathrm{E}+03$ & & $1.73 \mathrm{E}+03$ & & $2.64 \mathrm{E}+03$ & & $2.20 \mathrm{E}+03$ & $5.38 \mathrm{E}+02$ & 24.5 \\
\hline Oxalate & & $1.15 \mathrm{E}+03$ & & $1.00 \mathrm{E}+03$ & & $9.98 \mathrm{E}+02$ & & $1.12 \mathrm{E}+03$ & & $1.07 \mathrm{E}+03$ & $7.91 \mathrm{E}+01$ & 7.4 \\
\hline sp. G. $(\mathrm{g} / \mathrm{mL})$ & & 1.2255 & & 1.2283 & & 1.229 & & 1.2323 & & 1.23 & 0.00 & 0.2 \\
\hline $\begin{array}{c}\text { insoluble } \\
\text { solids(wt } \%)\end{array}$ & $<$ & 0.002 & $<$ & 0.002 & $<$ & 0.002 & $<$ & 0.002 & $<$ & 0.00 & 0.00 & 0.0 \\
\hline $\begin{array}{l}\text { soluble solids } \\
\text { (wt } \%)\end{array}$ & & 30.98 & & 30.58 & & 32.04 & & 32.43 & & 31.51 & 0.87 & 2.8 \\
\hline Free $\mathrm{OH}(\mathrm{M})$ & & 1.1531 & & 1.207 & & 1.2879 & & 1.3229 & & 1.24 & 0.08 & 6.2 \\
\hline $\mathrm{AlO}_{2}(\mathrm{M})$ & & NA & & NA & & NA & & NA & & & & \\
\hline Carbonate(M) & & NA & & $\mathrm{NA}$ & & NA & & $\mathrm{NA}$ & & & & \\
\hline \multicolumn{13}{|c|}{ Atomic Absorption } \\
\hline & & $(\mathrm{mg} / \mathrm{L})$ & & $(\mathrm{mg} / \mathrm{L})$ & & $(\mathrm{mg} / \mathrm{L})$ & & $(\mathrm{mg} / \mathrm{L})$ & & $(\mathrm{mg} / \mathrm{L})$ & $(\mathrm{mg} / \mathrm{L})$ & \\
\hline $\mathrm{Na}$ & & NA & & NA & & NA & & NA & & & & \\
\hline $\mathrm{K}$ & & $1.06 \mathrm{E}+03$ & & $9.39 \mathrm{E}+02$ & & $8.98 \mathrm{E}+02$ & & $9.11 \mathrm{E}+02$ & & $9.51 \mathrm{E}+02$ & $7.21 \mathrm{E}+01$ & 7.6 \\
\hline As & & $2.84 \mathrm{E}-01$ & & $2.36 \mathrm{E}-01$ & & $2.14 \mathrm{E}-01$ & & $2.85 \mathrm{E}-01$ & & $2.55 \mathrm{E}-01$ & $3.55 \mathrm{E}-02$ & 13.9 \\
\hline
\end{tabular}




\begin{tabular}{|c|c|c|c|c|c|c|c|c|c|c|c|c|}
\hline $\mathrm{Se}$ & & 2.19E-01 & & $2.65 \mathrm{E}-02$ & & $9.65 \mathrm{E}-02$ & & $2.25 \mathrm{E}-01$ & & $1.42 \mathrm{E}-01$ & $9.70 \mathrm{E}-02$ & 68.4 \\
\hline $\mathrm{Hg}$ & $<$ & $2.40 \mathrm{E}-02$ & $<$ & $1.98 \mathrm{E}-02$ & $<$ & $1.76 \mathrm{E}-02$ & $<$ & $1.65 \mathrm{E}-02$ & $<$ & $1.95 \mathrm{E}-02$ & $3.31 \mathrm{E}-03$ & 17.0 \\
\hline Total U & $<$ & $1.00 \mathrm{E}+00$ & $<$ & $1.00 \mathrm{E}+00$ & $<$ & $1.00 \mathrm{E}+00$ & $<$ & $1.00 \mathrm{E}+00$ & $<$ & $1.00 \mathrm{E}+00$ & $0.00 \mathrm{E}+00$ & 0.0 \\
\hline \multicolumn{13}{|c|}{ Ion Selective Electrode } \\
\hline & & $(\mathrm{mg} / \mathrm{L})$ & & $(\mathrm{mg} / \mathrm{L})$ & & $(\mathrm{mg} / \mathrm{L})$ & & $(\mathrm{mg} / \mathrm{L})$ & & $(\mathrm{mg} / \mathrm{L})$ & $(\mathrm{mg} / \mathrm{L})$ & \\
\hline $\mathrm{Cl}$ & & 179.6 & & 188.5 & & 213.2 & & 218.34 & & $2.00 \mathrm{E}+02$ & $1.88 \mathrm{E}+01$ & 9.4 \\
\hline $\mathrm{F}$ & & 119.4 & & 105.85 & & 93.78 & $<$ & 10 & $<$ & $8.23 \mathrm{E}+01$ & $4.93 \mathrm{E}+01$ & 59.9 \\
\hline \multicolumn{13}{|c|}{ Total Inorganic Carbon/Total Organic Carbon (TIC/TOC) } \\
\hline & & $(\mathrm{mg} / \mathrm{L})$ & & $(\mathrm{mg} / \mathrm{L})$ & & $(\mathrm{mg} / \mathrm{L})$ & & $(\mathrm{mg} / \mathrm{L})$ & & $(\mathrm{mg} / \mathrm{L})$ & $(\mathrm{mg} / \mathrm{L})$ & \\
\hline TIC & & 5782 & & 5618 & & 6294 & & 5656 & & $5.84 \mathrm{E}+03$ & $3.12 \mathrm{E}+02$ & 5.3 \\
\hline TOC & & 11432 & & 11617 & & 11814 & & 10732 & & $1.14 \mathrm{E}+04$ & $4.71 \mathrm{E}+02$ & 4.1 \\
\hline
\end{tabular}




\section{Table B-2. Characterization of Envelope C (AN102) Evaporator: Concentrate}

CRAD-1 refers to ADS Nos. 300149077, 300149080, and 300149083.

CRAD-2 refers to ADS Nos. 300149078, 300149081, and 300149084.

TTP-1 refers to ADS No. 300148563A.

TTP-2 refers to ADS No. 300148563B.

\begin{tabular}{|c|c|c|c|c|c|c|c|c|c|c|c|}
\hline Sample ID & & CRAD-1 & & CRAD-2 & & TTP-1 & & TTP-2 & Average & St. Dev. & \% Rel.St.Dev. \\
\hline Dilution Factor & & 9.87 & & 9.87 & & 9.68 & & 9.68 & & & \\
\hline \multicolumn{12}{|l|}{ Radiochemical } \\
\hline & & $(\mu \mathrm{Ci} / \mathrm{mL})$ & & $(\mu \mathrm{Ci} / \mathrm{mL})$ & & $(\mu \mathrm{Ci} / \mathrm{mL})$ & & $(\mu \mathrm{Ci} / \mathrm{mL})$ & $(\mu \mathrm{Ci} / \mathrm{mL})$ & $(\mu \mathrm{Ci} / \mathrm{mL})$ & \\
\hline Co-60 & & $5.00 \mathrm{E}-02$ & & 4.93E-02 & & 4.58E-02 & & $4.48 \mathrm{E}-02$ & 0.047 & 4.98E-04 & 1 \\
\hline Cs-137 & & $7.18 \mathrm{E}-02$ & & $7.31 \mathrm{E}-02$ & & $6.99 \mathrm{E}-02$ & & $5.69 \mathrm{E}-02$ & 0.068 & $9.67 \mathrm{E}-04$ & 1 \\
\hline Eu-154 & & $4.44 \mathrm{E}-02$ & & $4.46 \mathrm{E}-02$ & & $3.49 \mathrm{E}-02$ & & $4.02 \mathrm{E}-02$ & 0.041 & $1.82 \mathrm{E}-04$ & 0.4 \\
\hline Eu-155 & & $3.29 \mathrm{E}-02$ & & $2.70 \mathrm{E}-02$ & & $3.15 \mathrm{E}-02$ & & $2.56 \mathrm{E}-02$ & 0.029 & $4.15 \mathrm{E}-03$ & 14 \\
\hline Am-241 & & $3.55 \mathrm{E}-02$ & & $2.14 \mathrm{E}-02$ & & $2.58 \mathrm{E}-02$ & & $1.15 \mathrm{E}-02$ & 0.024 & $9.93 \mathrm{E}-03$ & 42 \\
\hline Sr-90 & & $1.46 \mathrm{E}+00$ & & $1.35 \mathrm{E}+00$ & & & & & 1.40 & $8.11 \mathrm{E}-02$ & 6 \\
\hline \multicolumn{12}{|c|}{ ICP-Emission Spectrometry } \\
\hline & & $(\mathrm{mg} / \mathrm{L})$ & & $(\mathrm{mg} / \mathrm{L})$ & & $(\mathrm{mg} / \mathrm{L})$ & & $(\mathrm{mg} / \mathrm{L})$ & $(\mathrm{mg} / \mathrm{L})$ & $(\mathrm{mg} / \mathrm{L})$ & \\
\hline $\mathrm{Ag}$ & $<$ & $5.92 \mathrm{E}-01$ & $<$ & $5.92 \mathrm{E}-01$ & $<$ & $5.81 \mathrm{E}-01$ & $<$ & $5.81 \mathrm{E}-01$ & 0.59 & $6.61 \mathrm{E}-03$ & 1 \\
\hline $\mathrm{Al}$ & & $8.43 \mathrm{E}+03$ & & $8.35 \mathrm{E}+03$ & & $7.57 \mathrm{E}+03$ & & $7.47 \mathrm{E}+03$ & 7955 & $5.03 \mathrm{E}+02$ & 6 \\
\hline B & & $2.25 \mathrm{E}+01$ & & $2.20 \mathrm{E}+01$ & & $2.06 \mathrm{E}+01$ & & $2.07 \mathrm{E}+01$ & 21.4 & $9.53 \mathrm{E}-01$ & 4 \\
\hline $\mathrm{Ba}$ & $<$ & $1.97 \mathrm{E}-01$ & $<$ & $1.97 \mathrm{E}-01$ & $<$ & 1.94E-01 & $<$ & $1.94 \mathrm{E}-01$ & 0.20 & $2.20 \mathrm{E}-03$ & 1 \\
\hline $\mathrm{Ca}$ & & $1.76 \mathrm{E}+02$ & & $1.76 \mathrm{E}+02$ & & $1.61 \mathrm{E}+02$ & & $1.61 \mathrm{E}+02$ & 169 & $8.70 \mathrm{E}+00$ & 5 \\
\hline $\mathrm{Cd}$ & & $3.29 \mathrm{E}+01$ & & $3.29 \mathrm{E}+01$ & & $3.05 \mathrm{E}+01$ & & $3.02 \mathrm{E}+01$ & 31.6 & $1.49 \mathrm{E}+00$ & 5 \\
\hline $\mathrm{Ce}$ & & NM & & NM & $<$ & $3.05 \mathrm{E}+01$ & $<$ & $3.05 \mathrm{E}+01$ & & & \\
\hline $\mathrm{Co}$ & & $2.80 \mathrm{E}+00$ & & $2.79 \mathrm{E}+00$ & & $2.69 \mathrm{E}+00$ & & $2.67 \mathrm{E}+00$ & 2.74 & $6.81 \mathrm{E}-02$ & 2 \\
\hline $\mathrm{Cr}$ & & $1.17 \mathrm{E}+02$ & & $1.16 \mathrm{E}+02$ & & $1.06 \mathrm{E}+02$ & & $1.05 \mathrm{E}+02$ & 111 & $6.64 \mathrm{E}+00$ & 6 \\
\hline $\mathrm{Cu}$ & & $5.67 \mathrm{E}+00$ & & $5.54 \mathrm{E}+00$ & & $5.29 \mathrm{E}+00$ & & $5.19 \mathrm{E}+00$ & 5.42 & $2.21 \mathrm{E}-01$ & 4 \\
\hline $\mathrm{Fe}$ & & $3.84 \mathrm{E}+00$ & & $3.23 \mathrm{E}+00$ & & $3.04 \mathrm{E}+00$ & & $2.79 \mathrm{E}+00$ & 3.22 & $4.48 \mathrm{E}-01$ & 14 \\
\hline
\end{tabular}




\begin{tabular}{|c|c|c|c|c|c|c|c|c|c|c|c|}
\hline $\mathrm{La}$ & & $6.24 \mathrm{E}+00$ & & $6.16 \mathrm{E}+00$ & & $1.31 \mathrm{E}+00$ & & $1.69 \mathrm{E}+00$ & 3.85 & $2.72 \mathrm{E}+00$ & 71 \\
\hline $\mathrm{Li}$ & $<$ & $1.97 \mathrm{E}-01$ & $<$ & $1.97 \mathrm{E}-01$ & $<$ & $1.94 \mathrm{E}-01$ & $<$ & $1.94 \mathrm{E}-01$ & 0.20 & $2.20 \mathrm{E}-03$ & 1 \\
\hline $\mathrm{Mg}$ & & $1.09 \mathrm{E}-01$ & & $9.87 \mathrm{E}-02$ & $<$ & $9.68 \mathrm{E}-02$ & & $1.06 \mathrm{E}-01$ & 0.10 & $5.76 \mathrm{E}-03$ & 6 \\
\hline $\mathrm{Mn}$ & & $1.40 \mathrm{E}+00$ & & $1.16 \mathrm{E}+00$ & & $1.16 \mathrm{E}+00$ & & $1.13 \mathrm{E}+00$ & 1.21 & $1.27 \mathrm{E}-01$ & 10 \\
\hline Mo & & $3.46 \mathrm{E}+01$ & & $3.48 \mathrm{E}+01$ & & $3.22 \mathrm{E}+01$ & & $3.16 \mathrm{E}+01$ & 33.3 & $1.64 \mathrm{E}+00$ & 5 \\
\hline $\mathrm{Na}(\mathrm{M})$ & & 7.59 & & 7.67 & & 6.37 & & 6.29 & 6.98 & Molar & \\
\hline $\mathrm{Na}$ & & $1.74 \mathrm{E}+05$ & & $1.76 \mathrm{E}+05$ & & $1.46 \mathrm{E}+05$ & & $1.45 \mathrm{E}+05$ & 160430 & $1.73 \mathrm{E}+04$ & 11 \\
\hline $\mathrm{Ni}$ & & $2.00 \mathrm{E}+02$ & & $1.99 \mathrm{E}+02$ & & $1.83 \mathrm{E}+02$ & & $1.81 \mathrm{E}+02$ & 191 & $1.02 \mathrm{E}+01$ & 5 \\
\hline $\mathrm{P}$ & & $1.07 \mathrm{E}+03$ & & $1.04 \mathrm{E}+03$ & & $9.97 \mathrm{E}+02$ & & $1.00 \mathrm{E}+03$ & 1027 & $3.37 \mathrm{E}+01$ & 3 \\
\hline $\mathrm{Pb}$ & & $7.96 \mathrm{E}+01$ & & $7.97 \mathrm{E}+01$ & & $6.74 \mathrm{E}+01$ & & $6.94 \mathrm{E}+01$ & 74.0 & $6.52 \mathrm{E}+00$ & 9 \\
\hline $\mathrm{Si}$ & & $7.19 \mathrm{E}+01$ & & $7.02 \mathrm{E}+01$ & & $9.48 \mathrm{E}+01$ & & $9.39 \mathrm{E}+01$ & 82.7 & $1.35 \mathrm{E}+01$ & 16 \\
\hline $\mathrm{Sn}$ & & $2.27 \mathrm{E}+01$ & & $2.61 \mathrm{E}+01$ & & $1.41 \mathrm{E}+01$ & & $1.60 \mathrm{E}+01$ & 19.7 & $5.65 \mathrm{E}+00$ & 29 \\
\hline $\mathrm{Sr}$ & & $2.03 \mathrm{E}+02$ & & $2.03 \mathrm{E}+02$ & & $1.84 \mathrm{E}+02$ & & $1.83 \mathrm{E}+02$ & 193 & $1.13 \mathrm{E}+01$ & 6 \\
\hline Tc & & NM & & NM & & NM & & NM & NM & NM & NM \\
\hline $\mathrm{Ti}$ & $<$ & $1.97 \mathrm{E}-01$ & $<$ & $1.97 \mathrm{E}-01$ & $<$ & $3.39 \mathrm{E}-01$ & $<$ & $1.94 \mathrm{E}-01$ & 0.23 & 7.14E-02 & 31 \\
\hline $\mathrm{V}$ & & $6.91 \mathrm{E}-01$ & & 4.74E-01 & & $8.52 \mathrm{E}-01$ & & 6.49E-01 & 0.67 & $1.55 \mathrm{E}-01$ & 23 \\
\hline $\mathrm{Zn}$ & & $1.97 \mathrm{E}+00$ & & $1.85 \mathrm{E}+00$ & & $1.72 \mathrm{E}+00$ & & $1.72 \mathrm{E}+00$ & 1.82 & $1.20 \mathrm{E}-01$ & 7 \\
\hline $\mathrm{Zr}$ & & $1.26 \mathrm{E}+00$ & & $1.17 \mathrm{E}+00$ & & $1.68 \mathrm{E}+00$ & & $1.48 \mathrm{E}+00$ & 1.40 & $2.29 \mathrm{E}-01$ & 16 \\
\hline \multicolumn{12}{|l|}{ IC-Anions } \\
\hline & & $(\mathrm{mg} / \mathrm{L})$ & & $(\mathrm{mg} / \mathrm{L})$ & & $(\mathrm{mg} / \mathrm{L})$ & & $(\mathrm{mg} / \mathrm{L})$ & $(\mathrm{mg} / \mathrm{L})$ & $(\mathrm{mg} / \mathrm{L})$ & \\
\hline Chloride & & $1.76 \mathrm{E}+03$ & & $1.96 \mathrm{E}+03$ & & & & & 1861 & $1.47 \mathrm{E}+02$ & 8 \\
\hline Fluoride & & $1.02 \mathrm{E}+03$ & & $1.11 \mathrm{E}+03$ & & $8.71 \mathrm{E}+02$ & & $9.10 \mathrm{E}+02$ & 976 & $1.06 \mathrm{E}+02$ & 11 \\
\hline Formate & & $6.09 \mathrm{E}+03$ & & $6.79 \mathrm{E}+03$ & & $5.37 \mathrm{E}+03$ & & $5.40 \mathrm{E}+03$ & 5914 & $6.73 \mathrm{E}+02$ & 11 \\
\hline Nitrite & & $4.71 \mathrm{E}+04$ & & $4.61 \mathrm{E}+04$ & & $4.15 \mathrm{E}+04$ & & $4.40 \mathrm{E}+04$ & 44682 & $2.51 \mathrm{E}+03$ & 6 \\
\hline Nitrate & & $1.16 \mathrm{E}+05$ & & $1.23 \mathrm{E}+05$ & & $1.02 \mathrm{E}+05$ & & $1.06 \mathrm{E}+05$ & 111811 & $9.69 \mathrm{E}+03$ & 9 \\
\hline Sulfate & & $7.22 \mathrm{E}+03$ & & $7.92 \mathrm{E}+03$ & & $6.36 \mathrm{E}+03$ & & $6.61 \mathrm{E}+03$ & 7026 & $6.94 \mathrm{E}+02$ & 10 \\
\hline Phosphate & & $1.97 \mathrm{E}+03$ & & $2.36 \mathrm{E}+03$ & & $1.77 \mathrm{E}+03$ & & $1.96 \mathrm{E}+03$ & 2015 & $2.47 \mathrm{E}+02$ & 12 \\
\hline Oxalate & & $9.48 \mathrm{E}+02$ & & $1.08 \mathrm{E}+03$ & & $8.71 \mathrm{E}+02$ & & $9.20 \mathrm{E}+02$ & 954 & $8.75 \mathrm{E}+01$ & 9 \\
\hline \multicolumn{12}{|c|}{ General Properties } \\
\hline sp. G. $(\mathrm{g} / \mathrm{mL})$ & & 1.30 & & 1.29 & & 1.32 & & 1.32 & 1.31 & 0.01 & 1 \\
\hline
\end{tabular}


WSRC-TR-2000-00469

SRT-RPP-2000-00043

Revision 1

\begin{tabular}{|c|c|c|c|c|c|c|c|}
\hline $\begin{array}{l}\text { insoluble solids } \\
\text { (wt.\%, washed) }\end{array}$ & NM & NM & 0.02 & 0.02 & 0.02 & & \\
\hline $\begin{array}{l}\text { insoluble solids } \\
\text { (wt\%, unwashed) }\end{array}$ & 0.28 & 0.30 & NM & NM & 0.29 & & \\
\hline $\begin{array}{l}\text { Soluble solids } \\
\text { (wt\%) }\end{array}$ & 40.00 & 40.00 & 42.30 & 42.40 & 41.18 & 1.36 & 3 \\
\hline Free $\mathrm{OH}^{-}(\mathrm{M})$ & $1.46 \mathrm{E}+00$ & $1.47 \mathrm{E}+00$ & & & 1.46 & 0.01 & 0.5 \\
\hline $\mathrm{AlO}_{2}^{-}(\mathrm{M})$ & $2.60 \mathrm{E}-01$ & $2.56 \mathrm{E}-01$ & & & 0.26 & 0.00 & 1 \\
\hline Carbonate (M) & $3.27 \mathrm{E}-01$ & $2.94 \mathrm{E}-01$ & & & 0.31 & 0.02 & 7 \\
\hline \multicolumn{8}{|c|}{ Atomic Absorption } \\
\hline $\mathrm{Na}(\mathrm{M})$ & $6.91 \mathrm{E}+00$ & $6.80 \mathrm{E}+00$ & $7.14 \mathrm{E}+00$ & $7.09 \mathrm{E}+00$ & 6.85 & & \\
\hline $\mathrm{Na}(\mathrm{mg} / \mathrm{L})$ & $1.59 \mathrm{E}+05$ & $1.56 \mathrm{E}+05$ & $1.64 \mathrm{E}+05$ & $1.63 \mathrm{E}+05$ & 160544 & $1.87 \mathrm{E}+03$ & 1.2 \\
\hline $\mathrm{K}(\mathrm{mg} / \mathrm{L})$ & $1.23 \mathrm{E}+03$ & $1.24 \mathrm{E}+03$ & $1.17 \mathrm{E}+03$ & $1.14 \mathrm{E}+03$ & 1196 & $1.22 \mathrm{E}+01$ & 1.0 \\
\hline
\end{tabular}


Table B-3. Characterization of Envelope C (AN102) Evaporator: Condensate

A single sample of condensate was tested in duplicate. The ADS No. for TTPWAT-1 and -2 was 300148567.

\begin{tabular}{|c|c|c|c|c|c|}
\hline Sample ID & & TTPWAT-1 & & TTPWAT-2 & Average \\
\hline \multicolumn{6}{|c|}{ Radiochemical: Gamma Pulse Height Analysis } \\
\hline & & $(\mu \mathrm{Ci} / \mathrm{mL})$ & & $(\mu \mathrm{Ci} / \mathrm{mL})$ & $(\mu \mathrm{Ci} / \mathrm{mL})$ \\
\hline Co-60 & $<$ & $3.62 \mathrm{E}-07$ & $<$ & $3.62 \mathrm{E}-07$ & $<3.62 \mathrm{E}-07$ \\
\hline Cs-137 & $<$ & $1.40 \mathrm{E}-06$ & $<$ & $1.00 \mathrm{E}-06$ & $<1.20 \mathrm{E}-06$ \\
\hline Eu-154 & $<$ & $1.38 \mathrm{E}-06$ & $<$ & $1.11 \mathrm{E}-06$ & $<1.25 \mathrm{E}-06$ \\
\hline Eu-155 & $<$ & $1.69 \mathrm{E}-06$ & $<$ & $1.95 \mathrm{E}-06$ & $<1.82 \mathrm{E}-06$ \\
\hline Am-241 & $<$ & $3.70 \mathrm{E}-06$ & $<$ & $3.23 \mathrm{E}-06$ & $<3.47 \mathrm{E}-06$ \\
\hline \multicolumn{6}{|c|}{ ICP-Emission Spectrometry } \\
\hline & & $(\mathrm{mg} / \mathrm{L})$ & & $(\mathrm{mg} / \mathrm{L})$ & $(\mathrm{mg} / \mathrm{L})$ \\
\hline $\mathrm{Ag}$ & & 0.009 & & 0.008 & 0.009 \\
\hline $\mathrm{Al}$ & & 0.084 & & 0.064 & 0.074 \\
\hline $\mathrm{B}$ & & 0.037 & & 0.020 & 0.029 \\
\hline $\mathrm{Ba}$ & & 0.007 & & 0.007 & 0.007 \\
\hline $\mathrm{Ca}$ & & 0.168 & & 0.146 & 0.157 \\
\hline $\mathrm{Cd}$ & $<$ & 0.003 & $<$ & 0.003 & $<0.003$ \\
\hline $\mathrm{Ce}$ & $<$ & 0.315 & $<$ & 0.315 & $<0.315$ \\
\hline $\mathrm{Co}$ & & 0.008 & & 0.006 & 0.007 \\
\hline $\mathrm{Cr}$ & & 0.007 & & 0.007 & $<0.007$ \\
\hline $\mathrm{Cu}$ & $<$ & 0.007 & $<$ & 0.007 & 0.007 \\
\hline $\mathrm{Fe}$ & & 0.041 & & 0.013 & 0.027 \\
\hline $\mathrm{La}$ & $<$ & 0.011 & $<$ & 0.011 & $<0.011$ \\
\hline $\mathrm{Li}$ & & 0.008 & & 0.003 & 0.006 \\
\hline $\mathrm{Mg}$ & & 0.019 & & 0.013 & 0.016 \\
\hline $\mathrm{Mn}$ & $<$ & 0.001 & $<$ & 0.001 & $<0.001$ \\
\hline Mo & $<$ & 0.006 & $<$ & 0.006 & $<0.006$ \\
\hline
\end{tabular}




\begin{tabular}{|c|r|r|r|r|}
\hline $\mathrm{Na}$ & 0.265 & 0.197 & 0.231 \\
\hline $\mathrm{Na}(\mathrm{M})$ & & $1.15 \mathrm{E}-05$ & $8.60 \mathrm{E}-06$ & $1.01 \mathrm{E}-05$ \\
\hline $\mathrm{Ni}$ & 0.015 & 0.012 & 0.014 \\
\hline $\mathrm{P}$ & & 0.042 & 0.034 & 0.038 \\
\hline $\mathrm{Pb}$ & & 0.033 & 0.040 & 0.037 \\
\hline $\mathrm{Si}$ & 0.020 & 0.551 & 0.286 \\
\hline $\mathrm{Sn}$ & & 0.022 & 0.018 & 0.020 \\
\hline $\mathrm{Sr}$ & $<$ & 0.001 & 0.001 & $<0.001$ \\
\hline $\mathrm{Ti}$ & & 0.011 & 0.006 & 0.009 \\
\hline $\mathrm{V}$ & & 0.008 & 0.007 & 0.008 \\
\hline $\mathrm{Zn}$ & & 0.020 & 0.006 & 0.013 \\
\hline $\mathrm{Zr}$ & & 0.019 & 0.011 & 0.015 \\
\hline
\end{tabular}

\section{IC Anions}

\begin{tabular}{|c|c|c|c|c|c|}
\hline \\
\hline & & $(\mathrm{mg} / \mathrm{L})$ & & $(\mathrm{mg} / \mathrm{L})$ & $(\mathrm{mg} / \mathrm{L})$ \\
\hline Chloride & $<$ & 20 & $<$ & 20 & $<20$ \\
\hline Fluoride & $<$ & 20 & $<$ & 20 & $<20$ \\
\hline Formate & $<$ & 100 & $<$ & 100 & $<100$ \\
\hline Nitrite & $<$ & 100 & $<$ & 100 & $<100$ \\
\hline Nitrate & $<$ & 100 & $<$ & 100 & $<100$ \\
\hline Sulfate & $<$ & 50 & $<$ & 50 & $<50$ \\
\hline Phosphate & $<$ & 100 & $<$ & 100 & $<100$ \\
\hline Oxalate & $<$ & 100 & $<$ & 100 & $<100$ \\
\hline \multicolumn{6}{|c|}{ Atomic Absorption } \\
\hline $\mathrm{Na}$ & & 0.2748 & & 0.2910 & 0.2829 \\
\hline $\mathrm{K}$ & & 0.0115 & & 0.0165 & 0.0140 \\
\hline
\end{tabular}


The following measurements were taken with a 5-mL calibrated pipette. One disposal pipette tip was used for each of the six matrices. Samples were from the final collection bottles of each experimental portion. A slight correction factor was applied based on measurements of water and a standard sodium solution.

Table B-4. Characterization of Envelope C (AN102) Evaporator: Concentrate Density

\begin{tabular}{|c|c|c|c|c|c|c|}
\hline Sample & Mass, $5 \mathrm{~mL}$ & Density, g/mL & $\begin{array}{c}\text { Avg. Density } \\
\text { g/mL }\end{array}$ & $\begin{array}{l}\text { St. Dev. } \\
\text { g/mL }\end{array}$ & $\begin{array}{c}\% \text { Relative St. } \\
\text { Dev. }\end{array}$ & $\begin{array}{c}\text { Avg. Density, g/mL } \\
\text { (Bias-corrected) }\end{array}$ \\
\hline \multirow{3}{*}{ Water } & 4.961 & 0.992 & \multirow{3}{*}{0.994} & \multirow{3}{*}{0.002} & \multirow{3}{*}{0.22} & \multirow{3}{*}{0.999} \\
\hline & 4.969 & 0.994 & & & & \\
\hline & 4.983 & 0.997 & & & & \\
\hline \multirow{3}{*}{$5.6 \mathrm{M} \mathrm{Na}$} & 60.93 & 1.219 & \multirow{3}{*}{1.223} & \multirow{3}{*}{0.004} & \multirow{3}{*}{0.31} & \multirow{3}{*}{1.229} \\
\hline & 6.13 & 1.226 & & & & \\
\hline & 6.12 & 1.224 & & & & \\
\hline \multirow{3}{*}{$\begin{array}{l}\text { Initial Boildown } \\
\text { (final sample) }\end{array}$} & 6.593 & 1.319 & \multirow{3}{*}{1.323} & \multirow{3}{*}{0.004} & \multirow{3}{*}{0.27} & \multirow{3}{*}{1.330} \\
\hline & 6.62 & 1.324 & & & & \\
\hline & 6.626 & 1.325 & & & & \\
\hline \multirow{3}{*}{$\begin{array}{l}\text { Volatiles portion } \\
\text { (final) }\end{array}$} & 6.761 & 1.352 & \multirow{3}{*}{1.354} & \multirow{3}{*}{0.002} & \multirow{3}{*}{0.12} & \multirow{3}{*}{1.361} \\
\hline & 6.777 & 1.355 & & & & \\
\hline & 6.767 & 1.353 & & & & \\
\hline \multirow{3}{*}{$\begin{array}{l}\text { Metals portion } \\
\text { (final) }\end{array}$} & 6.765 & 1.353 & \multirow{3}{*}{1.355} & \multirow{3}{*}{0.002} & \multirow{3}{*}{0.16} & \multirow{3}{*}{1.362} \\
\hline & 6.774 & 1.355 & & & & \\
\hline & 6.786 & 1.357 & & & & \\
\hline \multirow{3}{*}{$\begin{array}{l}\text { Semivolatiles } \\
\text { portion } \\
\text { (final) }\end{array}$} & 6.741 & 1.348 & \multirow{3}{*}{1.350} & \multirow{3}{*}{0.001} & \multirow{3}{*}{0.09} & \multirow{3}{*}{1.357} \\
\hline & 6.753 & 1.351 & & & & \\
\hline & 6.75 & 1.350 & & & & \\
\hline
\end{tabular}

Bias correction at room temperature: $\quad$ Water: $0.998 / 0.994=1.004$

Standard (5.6M Na): $1.23 / 1.223=1.006$

Average bias (correction factor) $=1.005$ 
WSRC-TR-2000-00469

SRT-RPP-2000-00043

Revision 1

\section{Appendix C: Organic Analyses}

The following report ${ }^{30}$ describes the volatile and semivolatile analyses conducted at SRTC on two concentrate and two condensate samples of Envelope C (AN102) evaporation products and one blank. Throughout this Appendix, "U" stands for undetected; "ADS No." stands for the sample number in SRTC's Analytical Development Section; MDL is the minimum detection limit; and RT is the retention time, in minutes, for gas chromatography analysis. A complete reporting of SW-846 organic analyses for evaporator feed and product streams is reported separately. ${ }^{1}$ Sample identification information is included below.

ADS No. $\quad$ Customer ID $\quad$ Description

3-150433 BNF-C-VOAConc Concentrate (VOA portion of experiment)

3-150434 BNF-C-VOACond Condensate (VOA portion of experiment)

3-150435 BNF-C-M60Conc Concentrate (Method 60 portion of experiment)

3-150436 BNF-C-M60Cond Condensate (Method 60 portion of experiment)

3-150437 BNF-C-Blnk Blank (Water only)

\section{Results}

VOC Analysis

Five aqueous samples were submitted for volatile and semivolatile organic compound (VOC and SVOC) analysis. Only THF in quantities delineated below was determined to be present in VOC analysis and the limit of detection is $2.5 \mu \mathrm{g} / \mathrm{L}$.

\section{Table C-1. VOC Results}

\begin{tabular}{lc} 
Sample ID & THF, $\mu \mathrm{g} / \mathrm{L}$ \\
\hline Concentrate (VOA) & 260 \\
Condensate (VOA) & 280 \\
Concentrate (M60) & $\mathrm{U}$ \\
Condensate (M60) & 72 \\
Blank & 3.8
\end{tabular}

The following is a list of the EPA-regulated VOC's for which the SRTC instrument, described in the Experimental section below, is routinely calibrated. All these compounds went undetected, i.e., "U", at levels ranging from 1 to $5 \mu \mathrm{g} / \mathrm{L}$.

Acetone

Benzene

Bromodichloromethane

Bromoform

${ }^{30}$ Crump, S., memorandum of analytical results, SRT-ADS-2001-0017, Aiken, SC, Jan. 16, 2001. 
WSRC-TR-2000-00469

SRT-RPP-2000-00043

Bromomethane

Carbon Disulfide

Chlorobenzene

Chloroform

1,1-Dichloroethane

1,1-Dichloroethene

trans-1,2-Dichloroethene

cis-1,3-Dichloropropene

Dibromochloromethane

2-Hexanone

Methylene Chloride

p+m-xylenes

Tetrachloroethene

1,1,1-Trichloroethane

1,1,2-Trichloroethane

Vinyl Acetate
2-Butanone [Methyl Ethyl Ketone]

Carbon Tetrachloride

Chloroethane

Chloromethane

1,2-Dichloroethane

cis-1,2-Dichloroethene

1,2-Dichloropropane

trans-1,3-Dichloropropene

Ethyl benzene

4-Methyl-2-Pentanone

o-Xylene

Styrene

1,1,2,2-Tetrachloroethane

Toluene

Trichloroethene

Vinyl Chloride

\section{$\underline{\text { SVOC Analysis }}$}

Revision 1

The semivolatile organic compound (SVOC) analysis results were performed and the results of the analysis are reported below, along with the minimum detection limit (MDL) for each sample. The approximate boiling range for SVOCs in this study is 150 to $500^{\circ} \mathrm{C}$. In addition, the SVOC method is effective for compounds that are extractable in dichloromethane.

\section{Concentrate (VOA) (ADS\# 3-150433)}

$\mathrm{MDL}=1 \mathrm{mg} / \mathrm{L}$

\begin{tabular}{|c|c|c|}
\hline$\underline{\mathrm{RT}, \min }$ & Analyte & ntration, $\mathrm{mg} / \mathrm{L}$ \\
\hline 7.95 & 4-Methyl-3-hexanol & 25 \\
\hline 12.02 & 5-Butyl-5-nonanol & 12 \\
\hline 11.97 & Unidentified & 9.0 \\
\hline 23.15 & Unidentified Nitrophthalate Ester & 8.1 \\
\hline 15.11 & 4,5-Dichlorophenylenediamine & 6.9 \\
\hline 12.15 & Unidentified & 5.5 \\
\hline 18.87 & Tributyl phosphate & 2.5 \\
\hline 18.47 & unidentified Nitroaromatic & 2.2 \\
\hline 16.83 & 2,7-Naphthalenediol & 1.3 \\
\hline 22.75 & Unidentified Nitrophthalate Ester & 1.0 \\
\hline 14.5 & Unidentified & 1.0 \\
\hline
\end{tabular}


WSRC-TR-2000-00469

SRT-RPP-2000-00043

Revision 1

Condensate (VOA) (ADS\# 3-150434)

$\mathrm{MDL}=0.2 \mathrm{mg} / \mathrm{L}$

$\underline{\mathrm{RT}, \min } \quad \underline{\text { Analyte }}$

$16.83 \quad 2,7-$ Naphthalenediol

Concentration, $\mathrm{mg} / \mathrm{L}$

18.87

Tributyl phosphate

0.37

0.30

Concentrate (M60) (ADS\# 3-150435)

$\mathrm{MDL}=0.35 \mathrm{mg} / \mathrm{L}$

$\underline{\text { RT, min } \quad \text { Analyte }}$

7.98

4-Methyl-3-hexanol

Concentration, $\mathrm{mg} / \mathrm{L}$

11.99

Unidentified

33

23.15

Unidentified Nitrophthalate Ester 12

12.02

15.11

5-Butyl-5-nonanol

4,5-Dichlorophenylenediamine $\quad 7.2$

12.16

Unidentified

6.0

Tributyl phosphate $\quad 2.6$

18.87

22.74

Unidentified Nitrophthalate Ester

1.8

30.49

Unidentified

1.0

16.83

2,7-Naphthalenediol

0.36

Condensate (M60) (ADS\# 3-150436)

$\mathrm{MDL}=0.2 \mathrm{mg} / \mathrm{L}$

$\underline{\mathrm{RT}, \min } \quad \underline{\text { Analyte }}$

16.83 2,7-Naphthalenediol

$18.87 \quad$ Tributyl phosphate

Concentration, $\mathrm{mg} / \mathrm{L}$

0.34

0.28

\section{Blank (ADS\# 3-150437)}

$\mathrm{MDL}=0.1 \mathrm{mg} / \mathrm{L}$

$\underline{\text { RT, min } \quad \text { Analyte }}$

$18.86 \quad$ Tributyl phosphate

Concentration, $\mathrm{mg} / \mathrm{L}$

0.14

Very little surrogate recovery was observed in the two concentrate samples (3-150433 and 3-150435), but in each case 2-fluoro-6-nitrophenol was recovered. Surrogate spiking in this study was performed just prior to the final $\mathrm{pH}$ adjustment from $\mathrm{pH} 5$ to $\mathrm{pH} 1$, which was done at $0^{\circ} \mathrm{C}$ in an attempt to retard nitric acid attack. The final $\mathrm{pH}$ adjustment was carried out prior to the last extraction to produce protonated forms of the most acidic analytes of interest (e.g., pentachlorophenol). At $\mathrm{pH} 1$ sodium nitrite also undergoes protonation to form nitrous acid which, in the presence of organics, will react to give 
WSRC-TR-2000-00469

SRT-RPP-2000-00043

Revision 1

nitrated species. In the case of the concentrate samples reported below (3-150433 and 3$150435)$, nitrite was present which form nitrous acid upon final $\mathrm{pH}$ adjustment and gave the nitrated surrogate, 2-fluoro-6-nitrophenol (2-FNP), which was not seen in other samples because of the absence of nitrite ion.

\begin{tabular}{lcrrrrr} 
& & \multicolumn{5}{c}{ Surrogate Recoveries, \% } \\
Sample & ADS No. & \multicolumn{1}{c}{ S1 } & S2 & S3 & S4 & 2-FNP \\
Concentrate (VOA) & $(3-150433)$ & $\mathrm{U}$ & $\mathrm{U}$ & $\mathrm{U}$ & 0.7 & 6.4 \\
Condensate (VOA) & $(3-150434)$ & 19 & 33 & 48 & 29 & $\mathrm{U}$ \\
Concentrate (M60) & $(3-150435)$ & $\mathrm{U}$ & $\mathrm{U}$ & $\mathrm{U}$ & $\mathrm{U}$ & 6.5 \\
Condensate (M60) & $(3-150436)$ & 19 & 32 & 48 & 31 & $\mathrm{U}$ \\
Blank & $(3-150437)$ & 20 & 34 & 51 & 16 & $\mathrm{U}$
\end{tabular}

CERCLA Regulatory Limit, \% Rec

10-11021-11033-110 10-123

$\mathrm{S} 1=$ Surrogate 1 (Phenol-d5)

$\mathrm{S} 2=$ Surrogate 2 (4-Fluorophenol)

$\mathrm{S} 3=$ Surrogate 3 (4-Chlorophenol-d4)

$\mathrm{S} 4=$ Surrogate 4 (2,4,6-Tribromophenol)

Additionally, the SVOC study of this sample set included isotopic dilution analysis of tributyl phosphate (TBP) and N-nitrosodimethylamine (NDMA) using deuterium labelled isotopic diluents, TBP-d27 and NDMA-d6 respectively, as quantitation standards.

Selected ion monitoring was used for mass spectral determination of the analytes and diluents. The results of this study are shown below; all concentrations are given in mg/L. TBP quantitation values presented here are similar to, and much more reliable than the values given above because of the intrinsic accuracy of the method of quantitation employed.

\begin{tabular}{|c|c|c|c|c|}
\hline$\underline{\text { Sample }}$ & ADS No. & MDL & $\underline{\mathrm{TBP}}$ & NDMA \\
\hline Concentrate (VOA) & $(3-150433)$ & 0.1 & 2.5 & $\mathrm{U}$ \\
\hline Condensate (VOA) & $(3-150434)$ & 0.02 & 0.18 & 0.080 \\
\hline Concentrate (M60) & $(3-150435)$ & 0.1 & 2.0 & $\mathrm{U}$ \\
\hline Condensate (M60) & $(3-150436)$ & 0.02 & 0.22 & 0.24 \\
\hline Blank & $(3-150437)$ & 0.01 & 0.11 & $\mathrm{U}$ \\
\hline
\end{tabular}

\section{Experimental}

\section{VOC Analysis}

Water samples were analyzed by purge and trap Gas Chromatography / Mass Spectrometry (GC/MS) analysis to identify organic compounds in the samples. Analyses were carried out in building 773-A, laboratory B-159.

Volatile organic analyses were performed by Gas Chromatography - Mass Spectrometry (GC-MS), using the ADS method 2656 (Contract Laboratory Program SOW 7-93 for 
WSRC-TR-2000-00469

SRT-RPP-2000-00043

Revision 1

Volatile Organics). Samples were concentrated using an OI Analytical model 4460A Dynamic Headspace concentrator (Purge and Trap), using a three stage $(10 \mathrm{~cm}$ Carbopack B / 6 cm Carboxen 1000 / 1 cm Carboxen 1001) trap. Separation was performed with a Hewlett Packard 5890 series II gas chromatograph on a 30m x $0.75 \mathrm{~mm}$ VOCOL fused silica capillary column with 3- $\mu \mathrm{m}$ film thickness. Quantitation was performed with a Hewlett Packard model 5971 quadrupole mass spectrometer. A glass jet separator was inline prior to the inlet into the mass spectrometer. Internal standard and recovery surrogate compounds were added as specified in the Contract Laboratory Program (CLP) for volatile organics (SOW 7-93). The mass spectrometer tuning was confirmed within 12 hours prior to each measurement using 4-bromofluorobenzene. Tuning verification was performed against CLP tuning requirements, specifically to optimize CLP requirements for high mass sensitivity. 50/95 ratios which are between $8 \%-15 \%$ may require appropriate flagging if used for other purposes.

\section{SVOC Analysis}

Samples were prepared by extraction with dichloromethane at the original sample $\mathrm{pH}$, at $\mathrm{pH}$ 5, and again at $\mathrm{pH} 1-2$. Surrogate spiking was carried out prior to final acidification to evaluate the extent of analyte decomposition concurrent with nitrous acid formation ( $\mathrm{pKa}$ $=3.3$ ).

Gas Chromatography / Mass Spectrometry (GC/MS) analysis was employed to identify organic compounds in the samples. Analyses were carried out in building 773-A, laboratory B-123. It should be noted that ADS is not certified by DHEC (South Carolina Department of Health and Environmental Control) for NPDES (National Pollutant Discharge Elimination System) discharge compliance monitoring.

Analytical separations were carried out on a Hewlett Packard 6890 gas chromatograph, equipped with a $30 \mathrm{~m}$ DB-5 column, with 0.25 -mm diameter and $0.25 \mu \mathrm{m}$ film thickness. Quantitation was performed using a Hewlett Packard 5973 mass selective detector. The mass spectrometer tuning was confirmed within 24 hours prior to each measurement using perfluorotributylamine.

\section{Organic Analyses of Antifoam}

The Dow 1520-US antifoam used in the experiment was analyzed for particular volatile and semivolatile organic compounds using the same methods as described above. The following volatile compounds were detected (in $\mu \mathrm{g} / \mathrm{L}$, detection limit was $1 \mu \mathrm{g} / \mathrm{L}$ ).

Benzene: 2.0; 4-Methyl-2-pentanone (MIBK): 21; Toluene: 6.7; 1,2-Dibromoethane: 1.7; Chlorobenzene: 2.5; 1,2,3-Trichloropropane: 61 .

No semivolatile compounds were observed above the method detection limit of 0.025 $\mathrm{mg} / \mathrm{L}$. This includes some compounds of interest: 1,2,4-Trichlorobenzene, Naphthalene, Hexachlorobenzene, Aldrin, Pyrene, Bis(2-ethyl)hexylphthalate, Benzo [a] pyrene. 
WSRC-TR-2000-00469

SRT-RPP-2000-00043

Revision 1

\section{APPROVALS}

M. L. Crowder, Author

C. L. Crawford, Author

H. H. Saito, Author

T. B. Calloway, Jr., Author

L. V. Gibson, Jr., Author

M. A. Burdette, Author

S. L. Crump, Author

D. M. Ferrara, Technical Reviewer

C. T. Randall, Program Manager

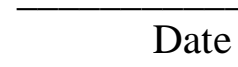

Date

Date

Date

Date

Date

Date

Date

Date 